\title{
Mineralogy and geochemistry of platinum- group elements in the Aguablanca Ni-Cu deposit (SW Spain)
}

\author{
R. Piña ${ }^{1}$, F. Gervilla ${ }^{2}$, L. Ortega ${ }^{1}$, and R. Lunar ${ }^{1}$ \\ ${ }^{1}$ Departamento de Cristalografía y Mineralogía, Facultad de Geología, \\ Universidad Complutense de Madrid, Madrid, Spain \\ ${ }^{2}$ Facultad de Ciencias, Instituto Andaluz de Ciencias de la Tierra, \\ Universidad de Granada-CSIC, Granada, Spain
}

\begin{abstract}
Summary
The Aguablanca Ni-Cu-(PGE) magmatic sulphide deposit is associated with a magmatic breccia located in the northern part of the Aguablanca gabbro (SW, Iberia). Three types of ores are present: semi-massive, disseminated, and chalcopyrite-rich veined ore. The principal ore minerals are pyrrhotite, pentlandite and chalcopyrite. A relatively abundant platinum-group mineral (PGM) assemblage is present and includes merenskyite, melonite, michenerite, moncheite and sperrylite. Moreover, concentrations of base and precious metals and micro-PIXE analyses were obtained for the three ore-types. The mineralogy and the mantlenormalised chalcophile element profiles strongly suggest that semi-massive ore represents $m s s$ crystallisation, whereas the disseminated ore represents an unfractionated sulphide liquid and the chalcopyrite-rich veined ore a $\mathrm{Cu}$-rich sulphide liquid. Palladium-bearing minerals occur commonly enclosed within sulphides, indicating a magmatic origin rather than hydrothermal. The occurrences and the composition of these minerals suggest that Pd was initially dissolved in the sulphides and subsequently exsolved at low temperatures to form bismutotellurides. Negative Pt and $\mathrm{Au}$ anomalies in the mantle-normalised chalcophile element profiles, a lack of $\mathrm{Cu}-\mathrm{S}$ correlation and textural observations (such as sperrylite losing its euhedral shape when in contact with altered minerals) suggest partial remobilisation of $\mathrm{Pt}, \mathrm{Au}$ and $\mathrm{Cu}$ by postmagmatic hydrothermal fluids after the sulphide crystallisation.
\end{abstract}




\section{Introduction}

The Azuablanca Ni-Cu deposit (15.7Mt grading 0.66 wt.\% Ni, 0.46 wt.\% Cu and $0.47 \mathrm{~g} / \mathrm{t}$ PGE) is an exceptional ore deposit from many points of view. It is located in one of the southernmost segments of the European Variscan chain, a collisional orozen mostly devoid of mazmatic sulphide mineralisations. Its discovery in 1993 was the first report of this type of deposit in southwestern Spain (Lunar et al., 1997; Ortega et al., 2000) and promoted an intense exploration program in the region and the identification of new favorable targets. Mining operations started in 2004. Two features of Aguablanca are unusual for a Ni-sulphide deposit (Tornos et al., 2001; Piña et al., 2006): 1) It is related to the development of calc-alkaline magmatism in a collisional margin, rather than in a rift environment, more common for these deposits (Barnes and Lightfoot, 2005), and 2) it is hosted by a subvertical mazmatic breccia which derived from an underlying concealed magmatic chamber. In this complex structural scenario, the distribution of ores and metals in the deposit was determined by a) the fractional crystallisation processes of the silicate melt and b) the timing of the sulphide liquid segregation relative to the emplacement of the breccia and its subsequent evolution. The post-mazmatic circulation of hydrothermal fluids overprinted the sub-solidus re-equilibrated magmatic assemblages and partially modified the deposit (Ortega et al., 2004). These key factors are now well constrained (Piña et al., 2005, 2006, and this work) and allow a better understanding of the zeochemical and mineralogical characteristics of the Azuablanca deposit.

The aim of this paper is to present a detailed study of the whole rock chemistry of the ore, the mineralogy of the platinum-group elements and the micro-PIXE analysis of the sulphides. These data are then discussed in order to explain the behaviour of the chalcophile elements and the origin of the PGM during the segregation and fractionation of the sulphide melt, the crystallisation of the sulphides and the late hydrothermal alteration processes.

\section{Geological background}

The Azuablanca deposit is located in the northern part of the Azuablanca intrusion. This intrusion crops out in the southern limb of the Olivenza-Monesterio antiform, a WNW-ESE trending, longitudinal, Variscan structure situated in the southern part of the Ossa-Morena Zone (OMZ) (Fiz. 1) (Riveiro et al., 1990; Sánchez-Carretero et al., 1990; Eguiluz et al., 2000). The OMZ is one of the tectonic domains of the Iberian Massif which includes extensive outcrops of Pre-Mesozoic rocks in the Iberian Peninsula. A detailed review of the Iberian Massif is given by Quesada (1991) and references therein.

The Aguablanca intrusion shows a subcircular outcrop of $3 \mathrm{~km}^{2}$ and comprises mostly massive zabbro merging to the south with diorite and to its northern zone with gabbronorite. It intrudes Early Cambrian volcanic, volcanoclastic and carbonate rocks (Bodonal-Cala Complex) which overlie Late Precambrian metasedimentary rocks mainly composed of graywackes and pyrite-rich black slates (Serie Negra Formation) (Eguiluz et al., 2000) (Fig. 1). Preliminary analytical data show that the black slates of the Serie Negra are rich in S (up to $5238 \mathrm{ppm}$ ) and show S/Se ratios 


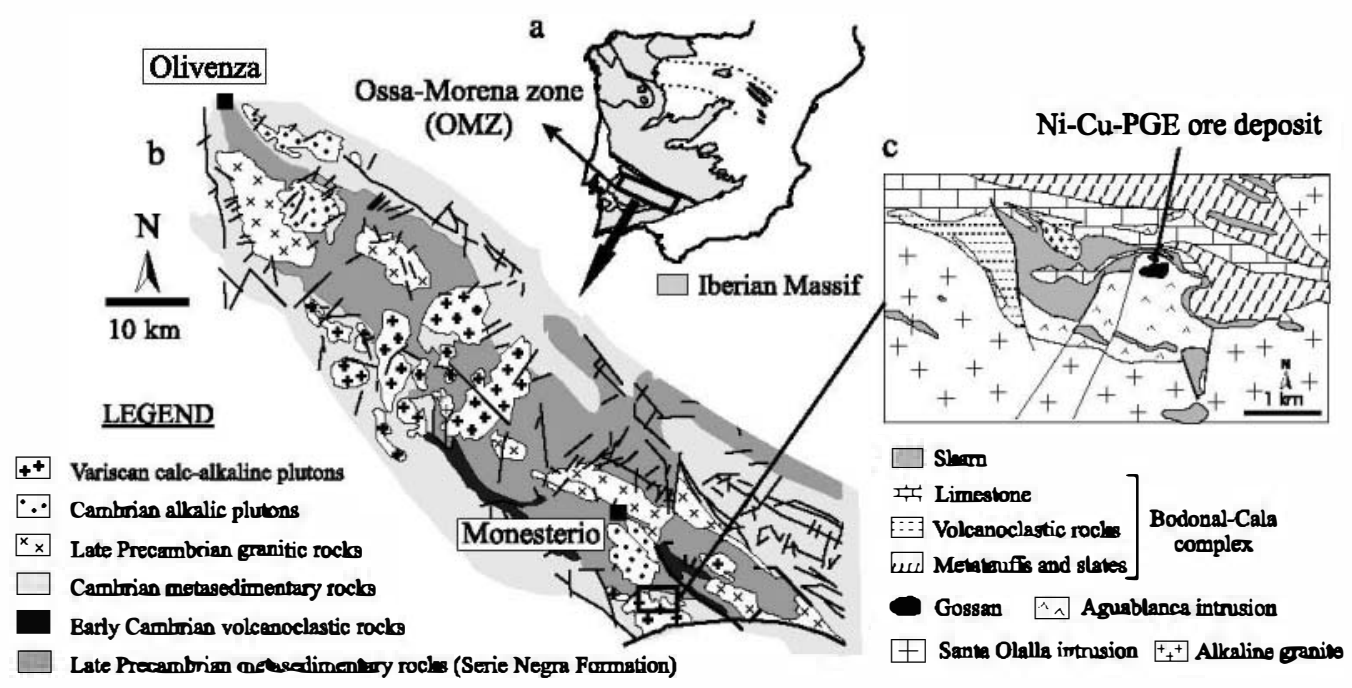

Fig. 1. a Location of the Ossa-Morena zone in the Iberian Massif. b Simplified regional geological map of the Olivenza-Monesterio antiform. c Schematic geological map of the Aguablanca area showing the location of the Ni-Cu-PGE ore (Lat. $37^{\circ} 57^{\prime} \mathrm{N}$; Long. $6^{\bullet} 11^{\prime} \mathrm{W}$ )

ranging from 184 to 3300 (1436 on average). Country rocks were metamorphosed during the Hercynian regional metamorphism which reached lower greenschistfacies conditions (Quesada and Munha, 1990). Along the contact with the intrusion, carbonate rocks were metamorphosed to skarn. The larger Santa Olalla intrusion occurs to the south of the Azuablanca intrusion (Fig. 1). It is formed by granodiorite and monzogranite in the core and tonalite and quartzdiorite at the rim (Tornos et al., 2001). Zircon U-Pb azes give an age of crystallisation for the Azuablanca intrusion of $338.6 \pm 0.8 \mathrm{My}$ (Romeo et al., 2004) which is in agreement with $\mathrm{Ar}^{40}-\mathrm{Ar}^{39}$ azes on phlogopite of $338 \pm 3 \mathrm{My}$ (Tornos et al., 2004). Zircon U-Pb data for the Santa Olalla intrusion give an age of crystallisation of $341 \pm 3 \mathrm{My}$ (Romeo et al., 2004). These ages indicate that both the Azuablanca and Santa Olalla intrusion intruded during the Hercynian orogeny, which in the OMZ involved a main magmatic event characterised by the emplacement of calc-alkaline igneous rocks in response to the formation of an Andean-type magmatic arc (Quesada et al., 1994).

\section{Analytical methods}

Platinum-group minerals were identified and analysed on carbon coated sections under back-scattered mode with a JEOL Superprobe JXA-8900 M electron microprobe at the Electron Microscopy Centre "Luis Bru" of the University Complutense of Madrid, Spain. Quantitative analyses of the PGM were determined by WDS $\mathrm{X}$-ray emission spectrometry. The accelerating voltage was $20 \mathrm{kV}$, the beam current $30 \mathrm{nA}$ and the counting periods ranged from 20 to $60 \mathrm{~s}$. Pure metals and synthetic alloys were used as standards. The X-ray lines analysed were AsL $\boldsymbol{\alpha}, \mathrm{Fe} K \boldsymbol{\beta}, \mathrm{S} K \boldsymbol{\alpha}$, $\mathrm{NiK} \boldsymbol{\alpha}, \mathrm{BiM} \boldsymbol{\kappa}, \mathrm{Te} L \boldsymbol{\alpha}, \mathrm{Os} L \boldsymbol{\alpha}, \mathrm{Ir} L \boldsymbol{\kappa}, \mathrm{Ru} L \boldsymbol{\alpha}, \mathrm{Rh} L \boldsymbol{\alpha}, \mathrm{Pt} L \boldsymbol{\alpha}$ and $\mathrm{P} \boldsymbol{\alpha} L \boldsymbol{\beta}$. The software applies the peak-overlap correction method. 
The micro-PIXE analyses of pyrrhotite, pentlandite, chalcopyrite and pyrite were carried out at the Scanning Proton Microprobe facility, University of Guelph, Department of Physics, Ontario, Canada. The analytical conditions were: beam current, between 3.75 and $8 \mathrm{nA}$ at $3 \mathrm{MeV}$; beam size, $3 \mu \mathrm{m} \times 6 \mu \mathrm{m}$; and counting times, between 120 and $190 \mathrm{~s}$. The data were calculated using the GUPIX program (Maxwell et al., 1989). Detection limits are different for each element and depend on the mineral analysed. They range between $6-15 \mathrm{ppm}$ for $\mathrm{Pd}, 6-13 \mathrm{ppm}$ for $\mathrm{Rh}$, 4-11ppm for $\mathrm{Ru}, 5-15 \mathrm{ppm}$ for $\mathrm{Se}, 25-800 \mathrm{ppm}$ for $\mathrm{Ni}, 17-1000 \mathrm{ppm}$ for $\mathrm{Cu}$, 11-400ppm for $\mathrm{Zn}, 5-14 \mathrm{ppm}$ for $\mathrm{Ag}$ and 6-30ppm for As.

Twenty-seven representative mineralised rock samples from the different oretypes were analysed for PGE, $\mathrm{Au} \mathrm{S,} \mathrm{Se,} \mathrm{Te,} \mathrm{Bi,} \mathrm{Ni,} \mathrm{Cu} \mathrm{and} \mathrm{Co.} \mathrm{PGE} \mathrm{and} \mathrm{Au} \mathrm{were}$ analysed by ICP-MS (nickel sulphide digest), $\mathrm{S}, \mathrm{Ni}, \mathrm{Cu}$ and $\mathrm{Co}$ by ICP-OES (multi-acid digest) and $\mathrm{Bi}, \mathrm{Se}$ and Te by ICP-MS (multi-acid digest) in Genalysis Laboratory Services Pty. Ltd., Maddington (Western Australia). Detection limits were $10 \mathrm{ppm}$ for S, $2 \mathrm{ppm}$ for $\mathrm{Se}, \mathbf{0 . 0 1} \mathrm{ppm}$ for $\mathrm{Te}$ and $\mathrm{Bi}$ and $1 \mathrm{ppm}$ for $\mathrm{Ni}, \mathrm{Cu}$ and $\mathrm{Co}$. For the noble metals, detection limits were $5 \mathrm{ppb}$ for $\mathrm{Au}, 2 \mathrm{ppb}$ for Ir, Os, $\mathrm{Ru}$, $\mathrm{Pd}$ and $\mathrm{Pt}$ and $1 \mathrm{ppb}$ for Rh.

\section{The Ni-Cu-PGE ore deposit}

\section{Structure of the ore deposit and host rocks}

The sulphide ore occurs within a subvertical (dipping $70-80^{\circ} \mathrm{N}$ ) funnel-like breccia body (Fig. 2) composed of rocks containing semi-massive and disseminated sulphides which host variable amounts of mafic-ultramafic fragments. The mineralised breccia body is roughly $600 \mathrm{~m}$ long, 350-400 m wide and more than $700 \mathrm{~m}$ deep. The orebody exhibits a concentric structure made up of: 1) a core formed by

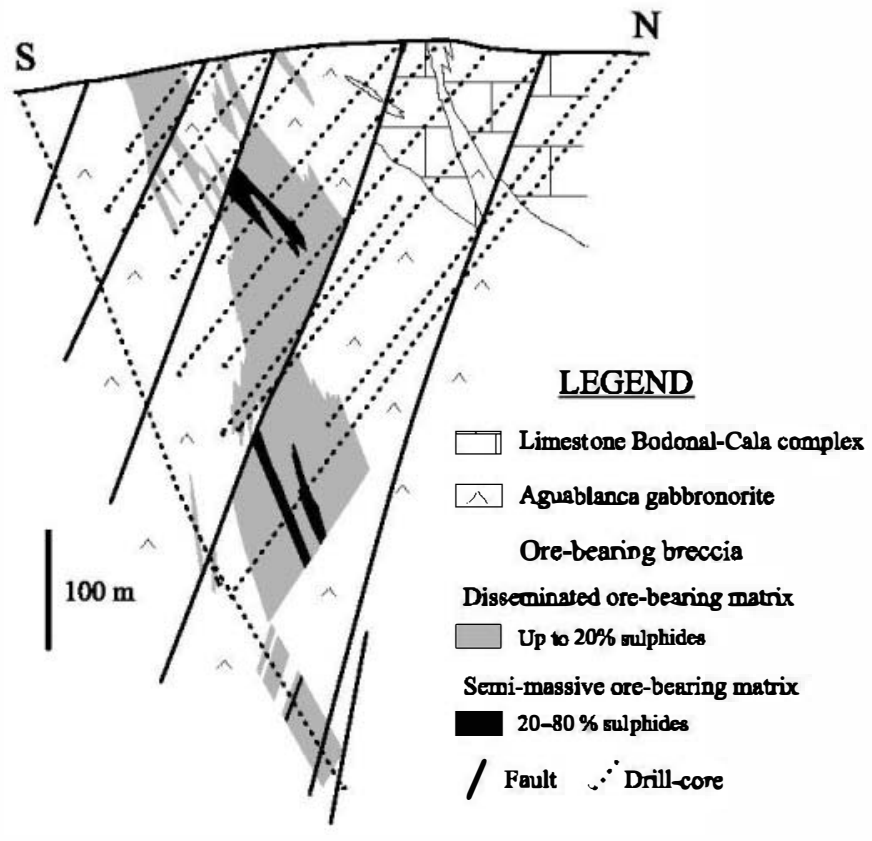

Fig. 2. North-south-oriented schematic cross section showing the ore-bearing breccia, based on drill core information. Mafic-ultramafic fragments are dispersed throughout the mineralised matrix 
a ground mass of $\mathrm{Ni}-\mathrm{Cu}-\mathrm{Fe}$ sulphides with cumulus orthopyroxene, clinopyroxene, plagioclase and/or minor olivine which includes abundant randomly distributed, barren or very slightly mineralised fragments of mafic-ultramafic rocks (semimassive ore); and 2) a zabbronorite envelope containing disseminated sulphides and minor mafic-ultramafic frazments (disseminated ore) (Fig. 2). The semimassive ore-bearing rocks resemble those described as leopardite at the Voisey's Bay ore deposit (Evans-Lamswood et al., 2000). The disseminated ore-bearing zabbronorites are predominantly hornblende-rich zabbronorite with minor norite, gabbro and gabbrodiorite, and grade outwards to free-sulphide rocks. Late subvertical, NE-oriented faults commonly truncate and displace the ore body.

The mafic-ulramafic fragments are centimetric size (up to $9 \mathrm{~cm}$ across), and have subangular to rounded shapes and sharp contacts with the matrix. They consist of different rock-types with typical cumulate textures: peridotite (including dunite, werhlite and harzburgite), pyroxenite (both ortho- and clinopyroxenite), zabbro (zabbro s.s., zabbronorite, norite and hornblende zabbro) and anorthosite (Piña et al., 2004, 2006). The fragments are interpreted to belong to a deep differentiated mafic-ulramafic complex brecciated during the shallow, tectonic intrusion of the sulphide and silicate magma matrix (Tornos et al., 2001; Piña et al., 2004, 2006).

All these rocks are variably altered to two postmagmatic, low-temperature mineral assemblazes: an early one with actinolite \pm chlorite \pm epidote \pm albite \pm serpentine, followed by talc \pm chlorite \pm carbonates.

\section{Ore mineralogy}

The ore mineral assemblaze is mainly composed of pyrrhotite, pentlandite, chalcopyrite and pyrite, with minor amounts of maznetite, ilmenite, platinum-group minerals (PGM), native gold, galena, tsumoite, tellurobismuthite, bismuthinite, members of the cobaltite-gersdorffite solid solution series, hessite, volinskyite, marcasite and violarite. Textural and mineralogical features of the ore have been described in detail by Ortega et al. (2004). Modal variations and the relative abundance of sulphides along the ore-body allow the identification of three main ore-types: semi-massive, disseminated and chalcopyrite veinlets:

(i) The semi-massive ore contains euhedral-subhedral grains of pyroxene, plagioclase and/or olivine, as well as mafic-ultramafic fragments. The modal sulphide content ranges between 20 and $85 \%$ (most of the samples have above $40 \%$ sulphides). Pyrrhotite is by far the predominant mineral $(34-77 \%$ of the bulk ore minerals). It forms large anhedral twinned crystals, is commonly surrounded by polycrystalline, chain-like aggrezates of pentlandite (11-34 mod.\%) and shows exsolution flames of pentlandite along grain boundaries of pyrrhotite and fractures. Chalcopyrite (commonly below 11 mod.\%) occurs as anhedral grains or as a polycrystalline intergrowths with pyrrhotite. Pentlandite:chalcopyrite ratio varies between 0.63 and 67.73. Isolated subhedral crystals of Cr-magnetite and ilmenite (up to 2\%) often occur within pyrrhotite and interstitial to sulphides.

(ii) The disseminated ore is formed by inequigranular azgregates of polymineralic sulphides comprising less than $20 \%$ of the rock, which occur interstitially to 
the silicate framework. Variable amounts of pyrrhotite (21-68 mod.\%) form irregular grains, frequently rimmed by grains of pentlandite $(3-18 \bmod . \%)$ and chalcopyrite (12-58 mod.\%). Chalcopyrite is commonly more abundant than pentlandite with pentlandite:chalcopyrite ratios below 1.0 .

(iii) The chalcopyrite veinlets are cross-cutting the disseminated and semi-massive ores as well as the mafic-ultramafic fragments of the breccia. They are very small $(<10 \mathrm{~cm}$ wide) and are mainly made up of massive chalcopyrite with minor amounts of irregular grains of pyrrhotite and pentlandite. Some subhedral zrains of a $\mathrm{Az}-\mathrm{Fe}-\mathrm{Ni}$ sulphide (likely argentopentlandite) are also included in chalcopyrite.

The sulphide assemblage described above is variably overprinted by hydrothermal pyrite (up to 16 mod.\%), mostly in areas with strong microfracturing and intense retrograde alteration. Textural features, cross-cutting relationships and $\mathrm{Ni}$ and Co contents allowed to identify three main episodes of pyrite precipitation $\left(\mathrm{Py}_{1}\right.$, $\mathrm{Py}_{2}+$ minor chalcopyrite, and $\left.\mathrm{Py}_{3}\right)$ in which pyrite mostly replaces pyrrhotite (Ortega et al., 2004). The precipitation of $\mathrm{Py}_{2}$ is coeval with the development of the actinolite \pm chlorite \pm epidote \pm albite \pm serpentine assemblage in the host silicate rocks, whereas $\mathrm{Py}_{3}$ formed with the late talc \pm chlorite \pm carbonates assemblage. During the $\mathrm{Py}_{2}$ episode, chalcopyrite locally occurs along cleavage planes of actinolite and chlorite.

\section{Whole-rock chemistry of the ore}

Sulphur concentrations are highly variable throughout the Azuablanca ores. In the semi-massive ores, $\mathrm{S}$ contents (12.7-30.4 wt.\%) are markedly higher than those of the disseminated ores (2.3-8 wt.\%) (Table 1) as expected from their higher sulphide contents. Sulphur and Se (7-74 ppm) are well correlated, with a correlation coefficient ( $\boldsymbol{\rho}$ ) of $\mathbf{0 . 9 7}$ (Table 2), indicating that the bulk of Se is in sulphide phases. $\mathrm{S} / \mathrm{Se}$ ratio varies from 2613 to 4710 ; these values are within the empirical range of mantle-derived sulphides (Naldrett, 1981). In semi-massive ores, $\mathrm{Ni}$ (2.6-6.4 wt.\%) commonly exceeds $\mathrm{Cu}(\mathbf{0} .2-3.7 \mathrm{wt} . \%)$ with $\mathrm{Ni} / \mathrm{Cu}$ ratios above 1 (average 7.3). This trend is reversed in the disseminated ores, where $\mathrm{Cu}$ contents $(0.5-4 \mathrm{wt} . \%)$ exceed those of $\mathrm{Ni}(\mathbf{0 . 4}-1.2 \mathrm{wt} . \%)$, with $\mathrm{Ni} / \mathrm{Cu}$ ratios varying from 0.28 to 1.29 (average 0.85 ). These data are consistent with the higher chalcopyrite modal contents observed in the disseminated ores with respect to those in the semi-massive ores. As expected, $\mathrm{Cu}$ content in the chalcopyrite veinlets is high (up to 10.62 wt.\%), with Ni remaining below $1 \mathrm{wt} . \%$. Nickel and S are positively correlated (Fig. 3a), indicating that $\mathrm{Ni}$ occurs primarily in the sulphide phase. In contrast, Cu shows no correlation with S (Fig. 3b). Cobalt ranges from 96 to 2480 ppm, exhibiting a good positive correlation with $\mathrm{S}$ and $\mathrm{Ni}(\boldsymbol{\rho}=\mathbf{0 . 9 0}$ and $\mathbf{0 . 8 5}$, respectively) (Table 2).

Highly variable Au amounts are characteristics of the Aguablanca ore (from 15 to $911 \mathrm{ppb}$ ). Disseminated ores show higher $\mathrm{Au}$ contents than the semi-massive ones (Table 1). In the chalcopyrite veinlets, $\mathrm{Au}$ abundance ranges from 106 to $833 \mathrm{ppb}$. There is no correlation of $\mathrm{Au}$ with $\mathrm{S}$ or PGE (Table 2), but there is a relatively good correlation between $\mathrm{Au}$ and $\mathrm{Cu}(\boldsymbol{\rho}=\mathbf{0 . 5 2 )}$ (Fig. 3c). 
Table 1. Compositional data of mineralised samples, Aguablanca ore deposit

\begin{tabular}{|c|c|c|c|c|c|c|c|c|c|c|c|c|c|c|c|c|c|c|c|c|c|}
\hline Sample & S & $\mathrm{Se}$ & $\mathrm{Te}$ & Bi & $\mathrm{Ni}$ & $\mathrm{Cu}$ & Co & $\mathrm{Au}$ & Os & Ir & $\mathbf{R u}$ & $\mathbf{R h}$ & $\mathbf{P t}$ & $\mathbf{P d}$ & $\begin{array}{l}\text { Total } \\
\text { PGE }\end{array}$ & $\mathrm{Ni} / \mathrm{Cu}$ & $\begin{array}{l}(\mathbf{P d}+\mathbf{P t}) / \\
(\mathrm{IPGE}+\mathbf{R h})\end{array}$ & $\mathbf{P d} / \mathrm{Ir}_{\mathrm{MN}}$ & $\begin{array}{l}\mathrm{Cu} / \\
\mathrm{Ni}_{\mathrm{MN}}\end{array}$ & $\mathrm{S} / \mathrm{Se}$ & $\begin{array}{l}\mathrm{Te} / \\
(\mathbf{P t}+\mathbf{P} \mathbf{d})\end{array}$ \\
\hline \multicolumn{22}{|c|}{ Leopardite-textured semi-massive ore } \\
\hline Leopardite-6 & 20.26 & 57 & 3.4 & 2.60 & 4.63 & 3.19 & 1534 & 403 & 32 & 98 & 56 & 88 & 1581 & 1438 & 3293 & 1.45 & 11.02 & 12.04 & 45.01 & 3554 & 1.13 \\
\hline AGU-55-136 & 25.15 & 74 & 4.9 & 1.43 & 3.7 & 3.67 & 2480 & 738 & 55 & 154 & 110 & 157 & 1337 & 1438 & 3251 & 1.01 & 5.83 & 7.66 & 64.80 & 3399 & 1.77 \\
\hline Leopardite-2 & 20.12 & 64 & 3.7 & 2.50 & 5.85 & 0.62 & 1861 & 107 & 34 & 96 & 68 & 113 & 1187 & 1771 & 3269 & 9.44 & 9.51 & 15.14 & 6.92 & 3144 & 1.25 \\
\hline $6554-235$ & 27.74 & 61 & 1.5 & 1.89 & 5.57 & 0.53 & 1539 & 24 & 93 & 232 & 143 & 224 & 200 & 482 & 1374 & 10.51 & 0.99 & 1.70 & 6.22 & 4547 & 2.20 \\
\hline $6580-279$ & 30.01 & 67 & 1.4 & 2.97 & 6.24 & 0.93 & 1740 & 15 & 91 & 211 & 130 & 227 & 446 & 621 & 1726 & 6.71 & 1.62 & 2.41 & 9.74 & 4479 & 1.31 \\
\hline $6715-415$ & 26.28 & 64 & 2.4 & 10.64 & 6.3 & 0.4 & 1225 & 49 & 21 & 57 & 26 & 98 & 84 & 907 & 1193 & 12.86 & 4.91 & 13.06 & 5.08 & 4106 & 2.42 \\
\hline $6580-281$ & 30.42 & 65 & 1.1 & 3.77 & 5.7 & 1.83 & 1790 & 56 & 75 & 219 & 121 & 263 & 467 & 676 & 1821 & 3.11 & 1.69 & 2.53 & 20.98 & 4680 & 0.96 \\
\hline $6715-416$ & 26.24 & 57 & 2.1 & 11.17 & 6.41 & 0.22 & 1101 & 20 & 25 & 61 & 31 & 93 & 30 & 1193 & 1433 & 29.14 & 5.82 & 16.05 & 2.24 & 4604 & 1.72 \\
\hline $6730-198$ & 14.68 & 39 & 5.3 & 4.92 & 3.46 & 0.24 & 941 & 93 & 16 & 39 & 24 & 49 & 823 & 891 & 1842 & 14.42 & 13.39 & 18.75 & 4.53 & 3763 & 3.09 \\
\hline \multicolumn{22}{|c|}{ Fragments-bearing semi-massive ore } \\
\hline Breccia-4 & 16.32 & 49 & 3 & 4.56 & 3.93 & 0.95 & 1035 & 170 & 20 & 63 & 38 & 61 & 952 & 1244 & 2378 & 4.14 & 12.07 & 16.20 & 15.79 & 3331 & 1.37 \\
\hline Breccia-1 & 12.74 & 36 & 1.5 & 1.29 & 3.09 & 0.73 & 981 & 21 & 19 & 56 & 42 & 73 & 681 & 823 & 1694 & 4.23 & 7.92 & 12.06 & 15.43 & 3539 & 1.00 \\
\hline $6629-39$ & 15.24 & 36 & 2 & 4.57 & 3.44 & 0.82 & 723 & 39 & 13 & 35 & 25 & 41 & 2244 & 768 & 3126 & 4.20 & 26.42 & 18.00 & 15.57 & 4233 & 0.66 \\
\hline $6758-544$ & 13.86 & 33 & 1.2 & 8.04 & 2.5 & 2.51 & 722 & 84 & 13 & 35 & 23 & 62 & 603 & 711 & 1447 & 1.03 & 9.88 & 16.67 & 63.32 & 4200 & 0.91 \\
\hline Breccia-10 & 16.49 & 36 & 1.5 & 1.51 & 2.73 & 2.06 & 849 & 335 & 15 & 45 & 31 & 49 & 576 & 699 & 1415 & 1.33 & 9.11 & 12.75 & 49.30 & 4581 & 1.18 \\
\hline Breccia-11 & 21.54 & 47 & 1.8 & 1.92 & 4.21 & 0.71 & 1236 & 63 & 18 & 56 & 37 & 64 & 352 & 793 & 1320 & 5.93 & 6.54 & 11.62 & 11.02 & 4583 & 1.57 \\
\hline \multicolumn{22}{|c|}{ Disseminate ore } \\
\hline $6580-108$ & 3.92 & 15 & 1.9 & 0.84 & 0.81 & 1.06 & 250 & 127 & 10 & 27 & 19 & 30 & 312 & 279 & 677 & 0.76 & 6.87 & 8.48 & 85.50 & 2613 & 3.21 \\
\hline $6749-390$ & 3.17 & 12 & 1.8 & 5.49 & 0.41 & 1.48 & 138 & 264 & b.d. & b.d. & 6 & 4 & 346 & 216 & 572 & 0.28 & 56.20 & & 235.84 & 2642 & 3.20 \\
\hline $6749-376$ & 8.07 & 18 & 0.7 & 3.01 & 1.07 & 1.2 & 634 & 22 & , & 39 & 18 & 56 & 78 & 234 & 434 & 0.89 & 2.56 & 4.92 & 73.27 & 4483 & 2.24 \\
\hline $6758-548$ & 3.56 & 12 & 1.6 & 4.18 & 0.43 & 1.13 & 181 & 167 & b.d. & b.d. & 4 & 4 & 276 & 128 & 412 & 0.38 & 50.50 & & 171.69 & 2970 & 3.96 \\
\hline $6554-246$ & 4.71 & 10 & 0.7 & 1.6 & 0.72 & 0.56 & 276 & 35 & 4 & 15 & 12 & 17 & 88 & 155 & 291 & 1.29 & 5.06 & 8.48 & 50.81 & 4710 & 2.88 \\
\hline AGU-5-29 & 3.76 & 14 & 1.9 & 5.89 & 0.8 & 0.85 & 212 & 341 & b.d. & 2 & 8 & 5 & 469 & 371 & 855 & 0.94 & 56.00 & 152.21 & 69.42 & 2686 & 2.26 \\
\hline $6554-169$ & 2.37 & 7 & 0.9 & 1.45 & 0.52 & 0.46 & 183 & 48 & b.d. & 6 & 5 & 8 & 147 & 132 & 298 & 1.13 & 14.68 & 18.05 & 57.79 & 3390 & 3.23 \\
\hline $6730-212$ & 4.61 & 13 & 2.4 & 3.13 & 0.87 & 1.11 & 271 & 301 & b.d. & 5 & 9 & 14 & 458 & 404 & 890 & 0.78 & 30.7 & 66.30 & 83.36 & 3545 & 2.78 \\
\hline $6715-452$ & 5.77 & 18 & 1.4 & 4.64 & 1.23 & 0.99 & 294 & 182 & b.d. & 3 & 5 & 6 & 185 & 386 & 585 & 1.24 & 40.79 & 105.57 & 52.59 & 3204 & 2.45 \\
\hline $6715-455$ & 6.07 & 14 & 1 & 2.7 & 0.36 & 4.03 & 96 & 911 & b.d. & 4 & 5 & 4 & 440 & 102 & 555 & 0.0 & 41.69 & 20.92 & 731.37 & 4334 & 1.85 \\
\hline \multicolumn{22}{|c|}{ Chalcopyrite veinlets } \\
\hline $6479-44.2$ & 4.7 & 12 & 0.8 & 2.33 & 0.99 & 1.62 & 276 & 106 & 5 & 15 & 10 & 21 & 45 & 371 & 467 & 0.61 & 8.16 & 20.29 & 106.91 & 3917 & 1.92 \\
\hline $6479-45.6$ & 7.07 & 19 & 1.3 & 3.26 & 0.97 & 4.76 & 284 & 833 & 3 & 8 & 8 & 12 & 737 & 618 & 1386 & 0.20 & 43.71 & 63.38 & 320.60 & 3721 & 0.96 \\
\hline $6554-221^{*}$ & 16.9 & & & & 0.7 & 10.6 & & 262 & 13 & 25 & 17 & 28 & 150 & 2513 & 2746 & 0.07 & 32.08 & 82.17 & 874.56 & & \\
\hline
\end{tabular}

* Data obtained from Ortega et al. (2004). Values of S, Ni and Cu are in wt.\%; Se, Te, Bi and Co in ppm; Au and PGE in ppb; $b . d$. below detection. Ratios $(\mathrm{Cu} / \mathrm{Ni})_{\mathrm{MN}}$ and $(\mathrm{Pd} / \mathrm{Ir})_{\mathrm{MN}}$ were calculated to a 100\% sulphide fraction following the method of Naldrett (1981) and then normalised to mantle values from McDonough and Sun (1995) 
Table 2. Correlation coefficients between the analysed elements

\begin{tabular}{|c|c|c|c|c|c|c|c|c|c|c|c|c|c|c|c|}
\hline & Os & Ir & $\mathrm{Ru}$ & $\mathrm{Rh}$ & $\mathrm{Pt}$ & Pd & $S$ & $\mathrm{Cu}$ & $\mathrm{Ni}$ & $\mathrm{Co}$ & $\mathrm{Te}$ & $\mathrm{Bi}$ & $\mathrm{Au}$ & $\mathrm{Ag}$ & $\mathrm{Se}$ \\
\hline Os & 1 & 0.99 & 0.98 & 0.97 & 0.11 & 0.03 & 0.79 & -0.14 & 0.67 & 0.74 & 0.11 & -0.08 & -0.13 & -0.24 & 0.74 \\
\hline Ir & & 1 & 9.9. & 0.98 & 0.13 & 0.23 & 0.83 & -0.10 & 0.74 & 0.83 & 0.17 & -0.12 & -0.19 & -0.29 & 0.81 \\
\hline $\mathrm{Ru}$ & & & 1 & 0.96 & 0.21 & 0.27 & 0.81 & -0.07 & 0.73 & 0.86 & 0.22 & -0.20 & -0.15 & -0.32 & 0.81 \\
\hline $\mathrm{Rh}$ & & & & 1 & 0.11 & 0.26 & 0.87 & -0.12 & 0.80 & 0.85 & 0.15 & -0.02 & -0.24 & -0.33 & 0.84 \\
\hline $\mathrm{Pt}$ & & & & & 1 & 0.36 & 0.21 & 0.03 & 0.26 & 0.38 & 0.54 & -0.15 & 0.21 & 0.05 & 0.35 \\
\hline $\mathrm{Pd}$ & & & & & & 1 & 0.55 & 0.54 & 0.45 & 0.77 & 0.71 & 0.17 & 0.02 & -0.19 & 0.79 \\
\hline$S$ & & & & & & & 1 & 0.01 & 0.93 & 0.90 & 0.33 & 0.22 & -0.22 & -0.29 & 0.97 \\
\hline $\mathrm{Cu}$ & & & & & & & & 1 & -0.28 & 0.02 & 0.00 & -0.20 & 0.52 & 0.72 & -0.03 \\
\hline $\mathrm{Ni}$ & & & & & & & & & 1 & 0.85 & 0.37 & 0.31 & -0.36 & -0.34 & 0.95 \\
\hline Co & & & & & & & & & & 1 & 0.52 & -0.03 & -0.10 & -0.38 & 0.96 \\
\hline $\mathrm{Te}$ & & & & & & & & & & & 1 & 0.08 & 0.14 & -0.17 & 0.50 \\
\hline $\mathrm{Bi}$ & & & & & & & & & & & & 1 & -0.20 & 0.15 & 0.18 \\
\hline $\mathrm{Au}$ & & & & & & & & & & & & & 1 & 0.71 & -0.15 \\
\hline $\mathrm{Ag}$ & & & & & & & & & & & & & & 1 & -0.29 \\
\hline $\mathrm{Se}$ & & & & & & & & & & & & & & & 1 \\
\hline
\end{tabular}

Bulk PGE concentrations range from 291 to $3293 \mathrm{ppb}$ and are well correlated with $S$ abundances (Fig. 3d). A group of semi-massive samples showing high $S$ contents but low bulk PGE concentration are characterised by being rich in secondary pyrite and exhibiting Pt negative anomalies in the mantle-normalised patterns as showed later. The main geochemical feature of PGE is the predominance of $\mathrm{Pt}$ and $\mathrm{Pd}$ over IPGE (Os, Ir, Ru) and $\mathrm{Rh}$ in all the analysed samples. $(\mathrm{Pt}+\mathrm{Pd}) /(\mathrm{IPGE}+\mathrm{Rh})$ ratios range from 0.99 to 56.20 with $\mathbf{8 0 \%}$ of the values above 5. Disseminated ores tend to have higher $(\mathrm{Pt}+\mathrm{Pd}) /(\mathrm{IPGE}+\mathrm{Rh})$ ratios than semi-massive ores (Table 1). IPGE and Rh show strong correlation each them (>0.96), but no correlation with Pt $(<0.21)$ or Pd $(<0.27)$ (Table 2). Osmium, Ir, $\mathrm{Ru}$ and $\mathrm{Rh}$ contents exhibit strong positive correlations with $\mathrm{S}(>\mathbf{0 . 7 9})$ (Table 2). Palladium correlates relatively well with $S(\rho=0.55)$ (Fig. 3e) and Pt is poorly correlated with $S(\rho=0.21)$ (Fig. 3f). It is worthy to note that the group of samples which has high $S$ contents and deviates from the main correlation trend contains abundant secondary pyrite replacing pyrrhotite. Palladium and Pt are better positively correlated with Te ( $\boldsymbol{\rho}=\mathbf{0 . 7 1}$ and $\mathbf{0 . 5 4}$, respectively) (Fig. 3g, h).

The mantle-normalised, PGE, Ni, Cu and $\mathrm{Au}$ patterns of the different ore-types are broadly similar, with overall positive slopes (Fig. 4). Gold and Pt exhibit a somewhat erratic distribution with significant variations in their abundances within individual ore-types. In some semi-massive ore samples, the patterns show pronounced negative $\mathrm{Au}$ and $\mathrm{Pt}$ anomalies which are also present in disseminated and chalcopyrite veined ores. The semi-massive samples with negative $\mathrm{Pt}$ anomalies are those with high $S$ and secondary pyrite abundances and relatively low bulk PGE contents in the Fig. 3d. Figure 4 shows significant differences between the different ore-types: semi-massive ores are slightly richer in $\mathrm{Ni}$, and notably richer in IPGE and Rh than disseminated ores, and show lower mantle-normalised Pd/Ir and $\mathrm{Cu} / \mathrm{Ni}$ ratios (9.5 and 19.9 vs. 22.7 and 119.3, respectively). The average pattern of the chalcopyrite veined ores shows an even steeper positive slope, with 

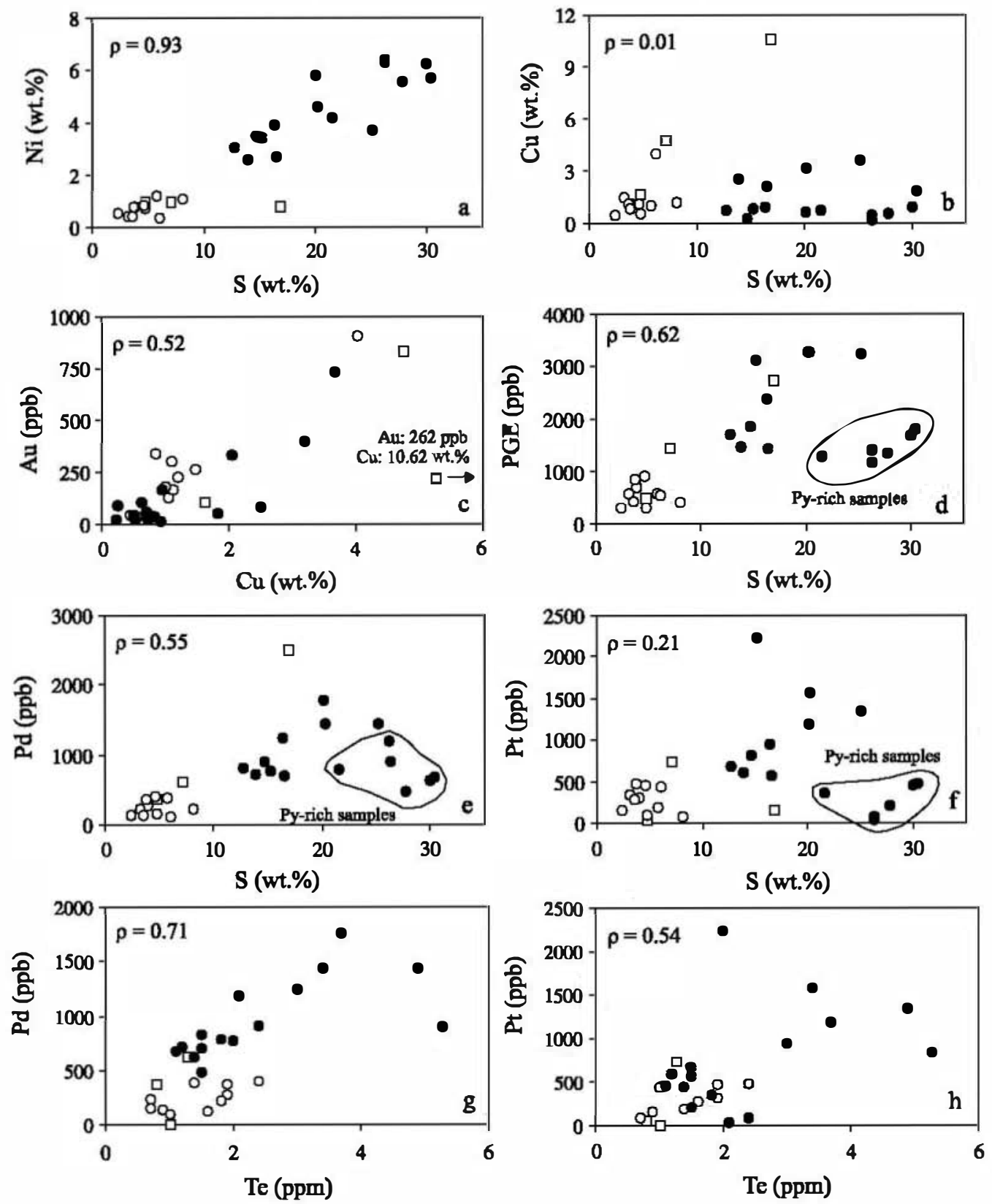

Fig. 3. Variation diagrams showing the correlations between different elements for samples from the ore-bearing breccia: a Ni vs. S; b Cu vs. S; c Au vs. Cu; total PGE vs. S; e Pd vs. S; f Pt vs. S; g Pd vs. Te; h Pt vs. Te

mantle-normalised $\mathrm{Pd} / \mathrm{Ir}$ and $\mathrm{Cu} / \mathrm{Ni}$ ratios averaging 48.3 and 296, respectively. Figure 5 shows that: 1) most of the samples fall into the field of the layered intrusions, and 2) there is a gradual decrease in the $\mathrm{Ni} / \mathrm{Pd}$ ratio with the increase 

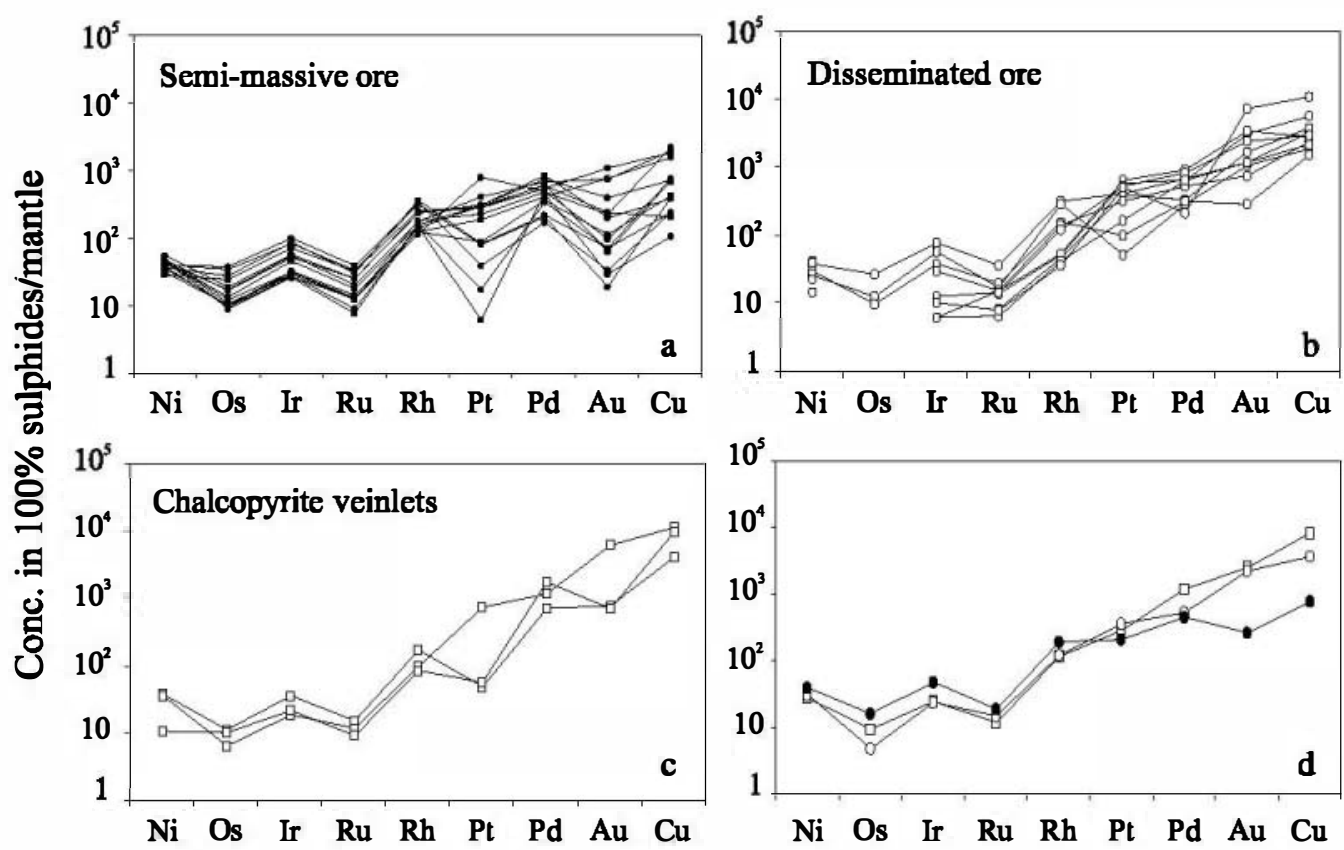

Fig. 4. Mantle-normalised metal patterns of the samples of the three ore-types from the orebearing breccia $(\mathbf{a}-\mathbf{c})$. Mantle-normalised metal patterns for the average values. Normalisation factors are from McDonough and Sun (1995)

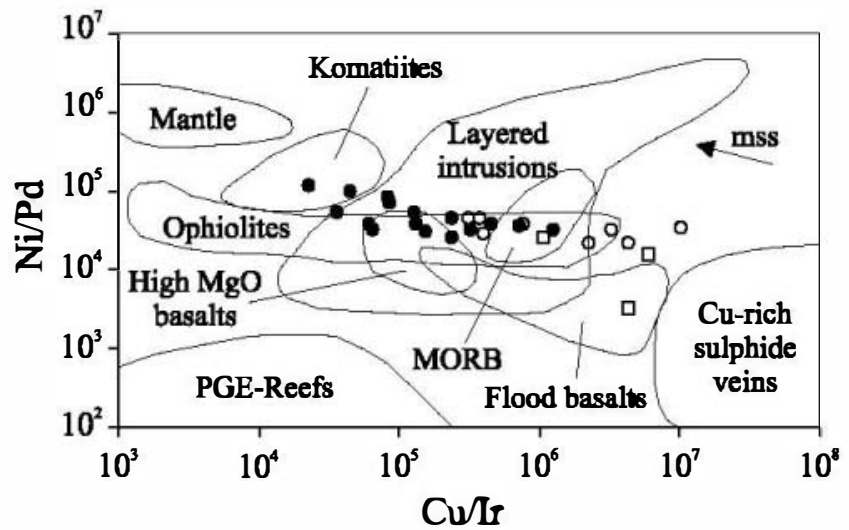

Fig. 5. Ni/Pd vs $\mathrm{Cu} / \mathrm{Ir}$ ratios of the samples from the Aguablanca deposit compared with selected compositional fields after Barnes et al. (1988). Symbols as for Figs. 3 and 4

of the $\mathrm{Cu} / \mathrm{Ir}$ ratio from the semi-massive to the disseminated ore and the chalcopyrite veined ores.

\section{Mineralogy of the platinum-group elements}

A total of 301 PGM grains were found in 45 polished sections representatives of the three ore-types. PGM are present in all ore-types, although they are substantially more abundant in the semi-massive $(70.8 \%$ of the whole) and the chalcopyrite veined $(21.2 \%)$ ores relative to the disseminated ore (uniquely $8.0 \%$ of the identified grains). Most PGM are spatially associated with base-metal sulphides. They occur included in sulphides (76\%), along sulphide-silicate (11\%) and 
sulphide-sulphide $(6 \%)$ grain boundaries, and only few of them are included in silicates $(\mathbf{7 \%})$. More than $\mathbf{9 0 \%}$ of the PGM grains are (Pd, Ni, Pt)-bismuthotellurides with the rest being sperrylite $\left(\mathrm{PtAs}_{2}\right)$, and phases containing Os-Ir-As-S, Ir-As-S and Ir-Pt-As (no quantitative analyses of these phases were obtained because of their very small grain sizes). (Pd, Ni, Pt)-bismuthotellurides consist, in a decreasing order of abundance, of merenskyite $\left(\mathrm{PdTe}_{2}\right)$, palladian melonite $\left(\mathrm{NiTe}_{2}\right)$, michenerite (PdBiTe) and moncheite $\left(\mathrm{PtTe}_{2}\right)$. Most PGM occur as single grains, although composite grains have occasionally been found. Some grains of the cobaltite-gersdorfitte solid solution series contain minor amounts of different PGE.

\section{Merenskyite, $\mathrm{Pd}(-\mathrm{Ni}, \mathrm{Pt}) \mathrm{Te}_{2}$}

Merenskyite represents $53 \%$ of the total PGM. In the disseminated and semimassive ores, it forms small $(<5-25 \mu \mathrm{m}$, but commonly less than $12 \mu \mathrm{m})$, rounded to subrounded grains hosted by pyrrhotite (Fig. 6a) and, more rarely, by pentlandite and chalcopyrite. It also occurs attached to the grain boundaries of sulphides (Fig. 6b). One unique grain has been observed in pyrite replacing pyrrhotite in semi-massive ores (Fig. 6c). Abundant grains of merenskyite, generally less than $10 \mu \mathrm{m}$ across, were found in the chalcopyrite veinlets. These grains invariably occur within chalcopyrite (Fig. 6d) and along chalcopyrite-silicate grain boundaries.

The analyses of the larger grains reveal a wide compositional range (Table 3; Fig. 7a) in agreement with the solid-solution series existing between merenskyite and melonite (Cabri, 2002) and between merenskyite and moncheite (Daltry and Wilson, 1997; Cabri, 2002). Merenkyite shows a wide substitution of Pd by Ni (from 0.4 to $6.5 \mathrm{wt} . \%)$ and Pt $(<17 \mathrm{wt} . \%)$. The grains found in the chalcopyrite veinlets do not contain Pt. There is an ubiquitous substitution of $\mathrm{Te}$ for $\mathrm{Bi}$, ranging from 4.5 to $29 \mathrm{wt} . \%$, in agreement with the compositions reported in the literature (Harney and Merkle, 1990; Gervilla and Kojonen, 2002; Cabri, 2002).

\section{Palladian melonite, $\mathrm{Ni}(-\mathrm{Pd}, \mathrm{Pt}) \mathrm{Te}_{2}$}

Palladian melonite only occurs in the semi-massive ores but represents $19 \%$ of the total PGM. The grain size rarely exceeds $10 \mu \mathrm{m}$, although some few crystals can be larger (up to $12 \mu \mathrm{m} \times 25 \mu \mathrm{m}$ ). It forms rounded or elongated grains included in pentlandite (Fig. 6e) and, rarely, in pyrrhotite, or occurs attached to pentlanditesilicate interfaces (Fig. 6f). Palladian melonite occasionally occurs in composite grains with tellurobismuthite or michenerite.

Electron-microprobe analyses reveal a wide substitution of $\mathrm{Ni}$ by $\mathrm{Pd}$ (from 3.46 to 12.30 wt.\% Pd) (Fig. 7a) and of Te by Bi (from 4.43 to 18.67 wt.\% Bi) (Table 3). Melonite also contains variable proportions of $\mathrm{Pt}(<7.6 \mathrm{wt} . \%)$, although two Pd-rich grains also exhibit high Pt contents (12.58 and 16.75 wt.\% Pt) (Fig. 7a).

\section{Michenerite, PdBiTe}

The modal proportion of michenerite $(17 \%)$ is similar to that of melonite, although it occurs both in the semi-massive and in the disseminated ores, but not in chalcopyrite veinlets. Its shape and size (normally less than $15 \mu \mathrm{m}$ ) vary considerably, 

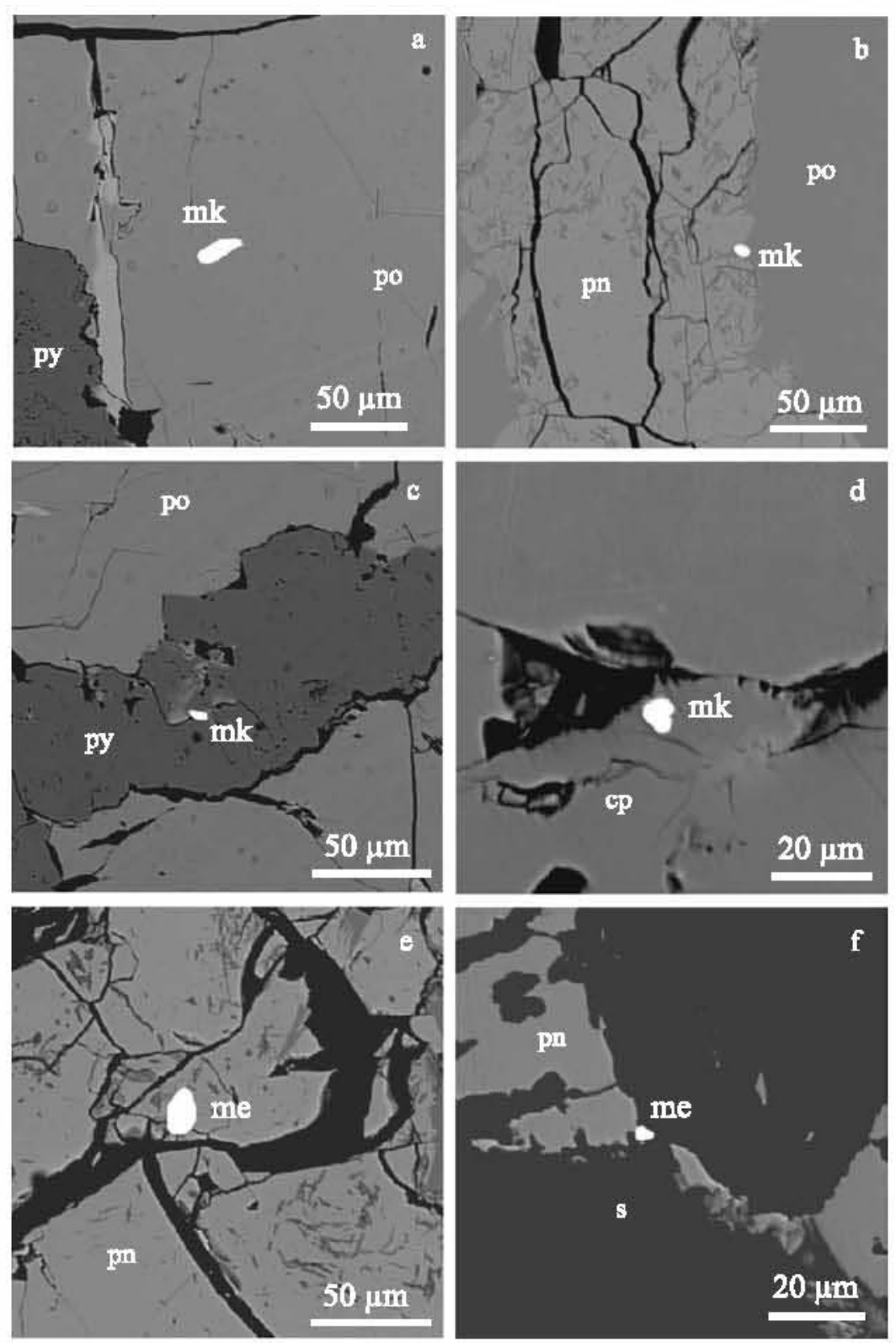

Fig. 6. Representative back-scattered electron microprobe images of the PGM. a Elongated merenskyite $(m k)$ within pyrrhorite $(p \bullet)$. b Subrounded merenskyite $(m k)$ at the interface

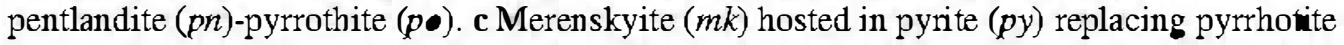
(p•). d Subrounded merenskyite $(m k)$ within chalcopyrite (cp). e Rounded melonite (me) within pentlandite $(p n)$. f Melonite (me) at pentlandite $(p n)$-silicate $(s)$ grain boundary. All examples are from the semi-massive ore, except $\mathbf{d}$, which is from a chalcopyrite veinlet

occurring as individual grains with rounded boundaries (Fig. 8a) and, rarely, with irregular and elongate shapes (Fig. 8b). The most common host-minerals are pyrrhotite, pentlandite and minor chalcopyrite. Some grains occur at the contact between sulphide and silicate. 
Table 3. Representative micreprobe analyses of the different

\begin{tabular}{|c|c|c|c|c|c|c|c|c|c|c|c|c|c|c|c|c|c|c|c|}
\hline \multirow{2}{*}{$\begin{array}{l}\text { Ore- } \\
\text { type }\end{array}$} & \multirow[t]{2}{*}{ Host } & Pd & $\mathrm{Pt}$ & $\mathrm{Ni}$ & $\mathrm{Fe}$ & $\mathrm{Te}$ & $\mathrm{Bi}$ & $S$ & As & Total & Pd & $\mathrm{Pt}$ & $\mathrm{Ni}$ & $\mathrm{Fe}$ & $\mathrm{Te}$ & $\mathrm{Bi}$ & $S$ & As & $\mathrm{Me} / \mathrm{nMe}$ \\
\hline & & \multicolumn{9}{|l|}{ wt. $\%$} & \multicolumn{9}{|l|}{ apfu } \\
\hline \multicolumn{20}{|c|}{ Merenskyite } \\
\hline SM & Po & 15.31 & 12.50 & 1.35 & 0.91 & 54.00 & 14.27 & 0.08 & n.d. & 98.42 & 0.58 & 0.26 & 0.09 & 0.07 & 1.71 & 0.28 & 0.01 & & 0.50 \\
\hline SM & Po & 12.22 & 16.58 & 2.93 & 1.19 & 64.11 & 5.37 & 0.04 & n.d. & 102.44 & 0.43 & 0.32 & 0.19 & 0.08 & 1.88 & 0.10 & 0.005 & & 0.51 \\
\hline SM & $\mathrm{Pn}$ & 18.72 & 0.52 & 5.44 & 0.73 & 61.87 & 15.11 & 0.02 & n.d. & 102.41 & 0.63 & 0.01 & 0.33 & 0.05 & 1.73 & 0.26 & 0.002 & & 0.51 \\
\hline SM & $C p$ & 14.93 & 13.01 & 1.55 & 0.39 & 51.25 & 18.5 & 0.03 & n.d. & 99.66 & 0.57 & 0.27 & 0.11 & 0.03 & 1.65 & 0.36 & 0.004 & & 0.49 \\
\hline SM & $C p$ & 17.10 & 5.57 & 2.99 & 0.88 & 52.03 & 20.97 & 0.10 & n.d. & 99.64 & 0.63 & 0.11 & 0.20 & 0.06 & 1.59 & 0.39 & 0.01 & & 0.50 \\
\hline SM & $\mathrm{Cp}$ & 20.37 & 4.43 & 1.26 & 0.80 & 45.85 & 27.52 & 0.06 & n.d. & 100.29 & 0.77 & 0.09 & 0.09 & 0.06 & 1.45 & 0.53 & 0.01 & & 0.51 \\
\hline SM & Cp-si1 & 11.27 & 14.84 & 4.24 & 1.07 & 65.75 & 5.25 & 0.04 & n.d. & 102.46 & 0.39 & 0.28 & 0.26 & 0.07 & 1.90 & 0.09 & 0.005 & & 0.50 \\
\hline SM & Sil & 21.71 & 0.91 & 2.63 & 0.71 & 57.30 & 17.44 & 0.04 & n.d. & 100.74 & 0.76 & 0.02 & 0.17 & 0.05 & 1.68 & 0.31 & 0.004 & & 0.50 \\
\hline D & Cp-si1 & 15.52 & 5.15 & 5.01 & 1.56 & 57.34 & 16.94 & n.d. & n.d. & 101.52 & 0.54 & 0.10 & 0.31 & 0.10 & 1.65 & 0.30 & & & 0.54 \\
\hline Cp-vein & $\mathrm{Cp}$ & 21.63 & 0.01 & 3.07 & 1.25 & 58.40 & 15.65 & 0.11 & n.d. & 100.12 & 0.75 & & 0.19 & 0.08 & 1.68 & 0.27 & 0.01 & & 0.52 \\
\hline Cp-vein & $\mathrm{Cp}$ & 21.83 & n.d. & 2.75 & 0.95 & 57.58 & 16.28 & 0.01 & n.d. & 99.40 & 0.77 & & 0.18 & 0.06 & 1.69 & 0.29 & 0.001 & & 0.51 \\
\hline \multicolumn{20}{|l|}{ Melonite } \\
\hline SM & Po & 7.66 & 16.75 & 5.68 & 1.37 & 65.41 & 5.18 & 0.07 & n.d. & 102.12 & 0.26 & 0.31 & 0.35 & 0.09 & 1.88 & 0.09 & 0.01 & & 0.51 \\
\hline SM & $\mathrm{Pn}$ & 3.46 & 5.17 & 12.94 & 1.53 & 68.42 & 8.45 & 0.37 & n.d. & 99.97 & 0.11 & 0.09 & 0.74 & 0.09 & 1.80 & 0.13 & 0.04 & & 0.52 \\
\hline SM & $\mathrm{Pn}$ & 5.25 & 4.77 & 11.48 & 1.44 & 60.99 & 16.05 & 0.11 & n.d. & 100.09 & 0.17 & 0.08 & 0.69 & 0.09 & 1.68 & 0.27 & 0.01 & & 0.53 \\
\hline SM & Pn & 4.32 & n.d. & 14.07 & 2.96 & 64.88 & 14.46 & 1.27 & n.d. & 101.96 & 0.13 & & 0.76 & 0.17 & 1.60 & 0.22 & 0.12 & & 0.55 \\
\hline \multicolumn{20}{|c|}{ Michenerite } \\
\hline SM & Po & 23.2 & n.d. & 0.04 & 0.69 & 29.34 & 47.22 & 0.02 & n.d. & 100.51 & 0.95 & & 0.003 & 0.05 & 1.00 & 0.98 & 0.003 & & 0.51 \\
\hline SM & Si1 & 22.95 & n.d. & 0.05 & 0.55 & 28.10 & 46.32 & 0.04 & n.d. & 98.01 & 0.96 & & 0.004 & 0.04 & 0.98 & 0.99 & 0.006 & & 0.51 \\
\hline SM & Pn-sil & 22.71 & n.d. & 0.75 & 1.01 & 29.20 & 47.76 & 0.05 & n.d. & 101.48 & 0.91 & & 0.05 & 0.07 & 0.98 & 0.98 & 0.01 & & 0.52 \\
\hline $\mathrm{D}$ & Po & 22.79 & n.d. & 0.16 & 0.89 & 29.56 & 47.29 & 0.02 & n.d. & 100.71 & 0.93 & & 0.01 & 0.07 & 1.00 & 0.98 & 0.003 & & 0.51 \\
\hline \multicolumn{20}{|c|}{ Moncheite } \\
\hline SM & Pn-po & 8.55 & 19.35 & 2.2 & 2.8 & 41.28 & 23.44 & 0.47 & n.d. & 98.09 & 0.34 & 0.41 & 0.16 & 0.21 & 1.35 & 0.47 & 0.06 & & 0.60 \\
\hline $\mathrm{D}$ & Si1 & 2.28 & 35.88 & 0.52 & 1.31 & 53.73 & 5.87 & 0.01 & n.d. & 99.6 & 0.09 & 0.80 & 0.04 & 0.10 & 1.84 & 0.12 & 0.002 & & 0.52 \\
\hline \multicolumn{20}{|c|}{ Sperrylite } \\
\hline SM & Po & 0.04 & 56.41 & 0.03 & 0.6 & 0.01 & 0.01 & 0.32 & 42.83 & 100.25 & 0.001 & 0.98 & 0.002 & 0.04 & & & 0.03 & 1.94 & 0.52 \\
\hline SM & Pn & n.d. & 57.77 & 0.15 & 0.09 & 0.08 & 0.05 & 0.36 & 40.87 & 99.37 & & 1.03 & 0.01 & & 0.002 & & 0.04 & 1.91 & 0.53 \\
\hline SM & Si1 & 0.09 & 54.85 & 0.11 & 1.64 & 0.41 & n.d. & 0.54 & 40.22 & 97.86 & 0.003 & 0.97 & 0.01 & 0.10 & 0.01 & & 0.06 & 1.85 & 0.51 \\
\hline $\mathrm{D}$ & Po & 0.12 & 51.28 & 0.04 & 2.63 & 0.01 & 0.01 & 2.14 & 44.18 & 100.41 & 0.003 & 0.81 & 0.002 & 0.14 & & & 0.21 & 1.82 & 0.47 \\
\hline
\end{tabular}

SM Semi-massive ore; $D$ disseminated ore; $C p$-vein chalcopyrite veinlets; $P \bullet$ pyrrhotite; $P n$ pentlandite; $C p$ chalcopyrite; Sil silicate; $n$.d. not detected; apfu atoms per formula unit based on a total of three atoms in the formula unit. Me/nMe Metal to non metal ratio. Because of the small size of the grains, there is generally interference with the ad jacent minerals and traces of $S$ and Fe are of ten detected, being ascribed to contamination from the host sulphides 


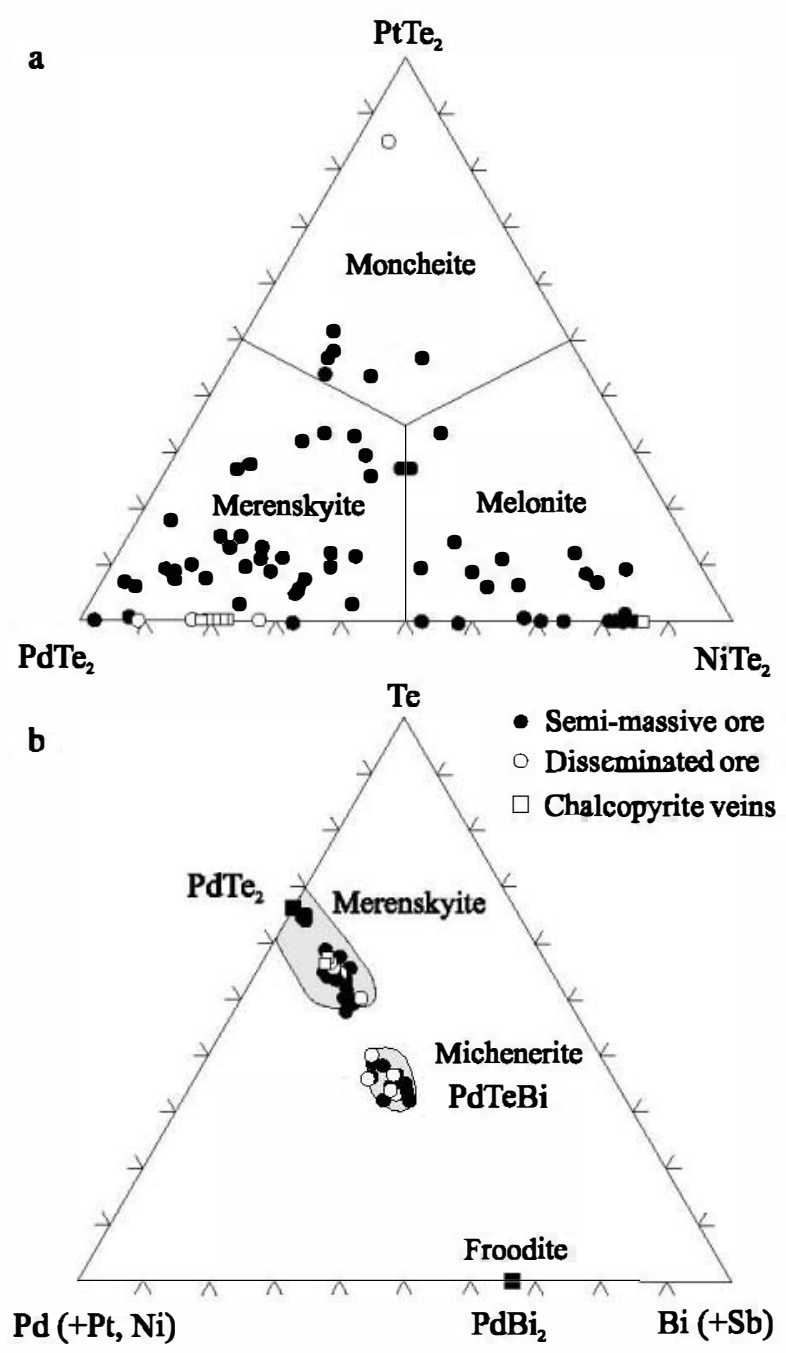

Fig. 7. a Modal proportions of merenskyite, melonite and moncheite from the ore-bearing breccia plotted in the $\mathrm{PdTe}_{2}-\mathrm{NiTe}_{2}-\mathrm{PtTe}$ diagram. b $\mathrm{Pd}(+\mathrm{Pt}, \mathrm{Ni})-\mathrm{Te}-\mathrm{Bi}(+\mathrm{Sb})$ diagram showing the compositional variation in at.\% of merenskyite and michenerite from the ore-bearing breccia. Shaded areas represent the compositional fields of the respective minerals reported in the literature taken from Harney and Merkle (1990)

The composition of the analysed grains reveals $\mathrm{Pd}$ contents ranging from 32 to 36 at.\%, Te from 33 to 39 at.\% and Bi from 26 to 34 at.\% (Fig. 7b). Pt contents are below detection limit and $\mathrm{Ni}$ is commonly below 1 wt.\% (Table 3). Traces of $\mathrm{Az}$ and $\mathrm{Sb}$ may substitute $\mathrm{Pd}$ and $\mathrm{Bi}$, respectively.

Sperrylite, PtAs 2

Sperrylite represents $5 \%$ of the total PGM found. It occurs in the semi-massive and in the disseminated ores. Two euhedral crystals occur inside pyrrhotite with sizes of $4 \mu \mathrm{m} \times 5 \mu \mathrm{m}$ and $20 \mathrm{~m} \times 35 \mu \mathrm{m}$, whereas one subhedral grain with a size of roughly $100 \mu \mathrm{m}$ is hosted by pentlandite in contact with chlorite (Fig. 8c). This grain shows that where the faces of the sperrylite crystal are adjacent to pentlandite, they show angular blocky shapes, but, where they are in contact with chlorite, the morphology of the crystal becomes irregular (Fig. 8c). Furthermore, two small $(<15 \mu \mathrm{m})$ crystals of sperrylite occur inside amphibole. These also exhibit corroded borders.

Sperrylite composition is almost stoichiometric with uniquely minor traces of Fe and $S(<1$ wt.\%) (Table 3$)$. 

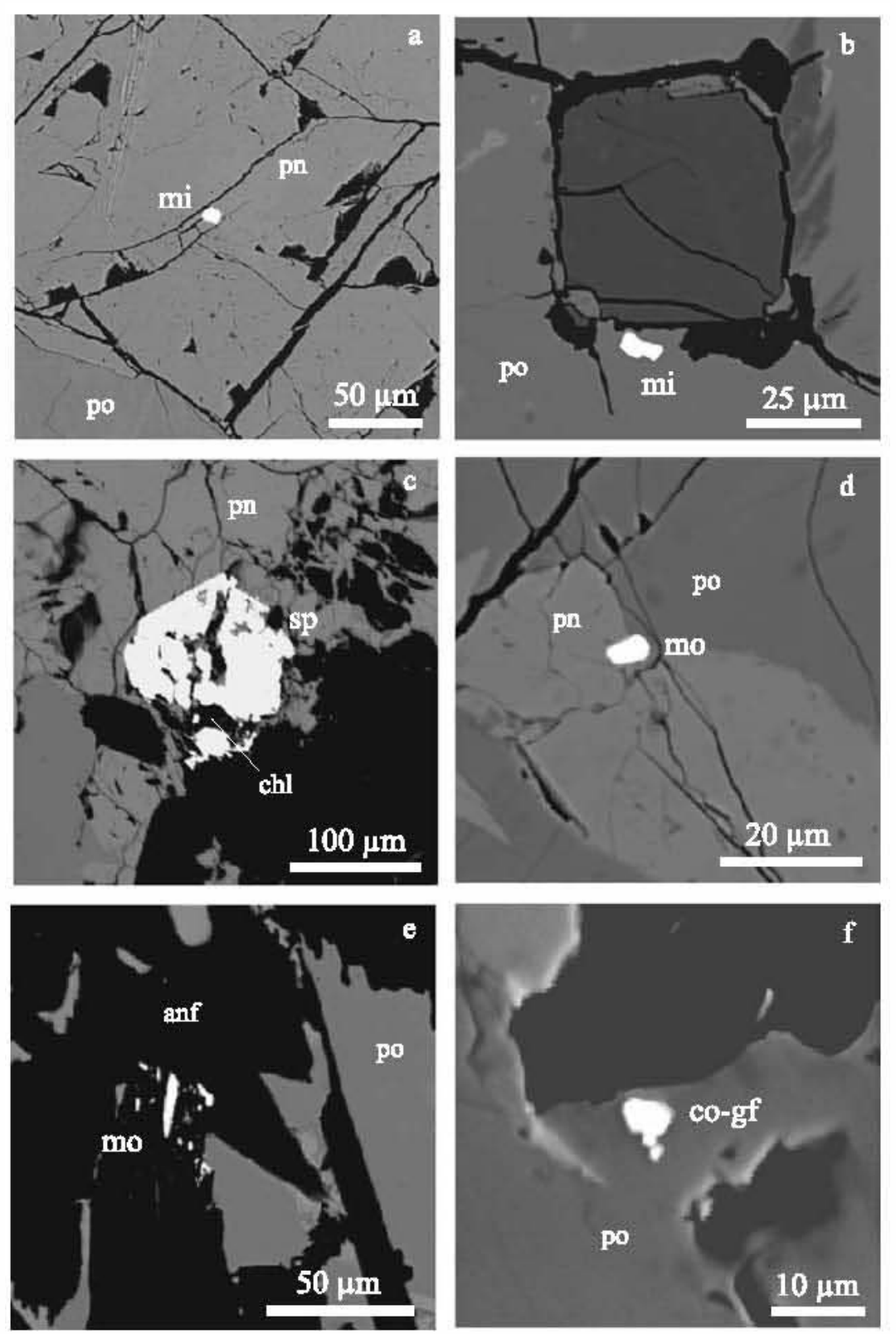

Fig. 8. Representative back-scattered electron microprobe images of the PGM. a Michenerite ( $m i$ ) with rounded boundaries within pentlandite ( $p n$ ). b Irregular, elongated michenerite $(m i)$ grain inside pyrrhorite $(p \bullet)$. c Single subhedral sperrylite $(s p)$ crystal inside pentlandite $(p n)$. Note the irregular shape of the sperrylite where it is in contact with chlorite $(c h l)$. d Subhedral moncheite $(m \bullet)$ at the interface pentlandite $(p n)$ pyrrhotite $(p \bullet)$. e Several moncheite $(m \bullet)$ grains inside secondary amphibole (amp). f Single idiomorphic crystal of the cobaltite-gersdorffite $(c-g f)$ solid solution hosted within pyrrhotite $(p \bullet)$. Microphotographs $\mathbf{a}-\mathbf{c}$ and $\mathbf{e}$ are from semi-massive ore, $\mathbf{d}$ and f from disseminated ore 
Moncheite, Pt (-Pd, Ni)Te 2

Moncheite is substantially much less frequent than the other PGM described. It only represents $4 \%$ of the total PGM and occurs mostly in the semi-massive ore, as small $(<10 \mu \mathrm{m})$, subrounded inclusions in pentlandite or in the interface pyrrhotitepentlandite (Fig. 8d). Several irregular, elongated grains were also observed included in hydrothermal amphibole in the disseminated ore (Fig. Se).

Its composition reveals extensive substitution of $\mathrm{Pt}$ for $\mathrm{Pd}$ (up to $10.46 \mathrm{wt}$ \%) and $\mathrm{Ni}$ (from 1.70 to 12.12wt.\%) (Fig. 7a), and of Te for Bi (from 11.39 to 25 wt.\%). However, the grains located inside amphibole (Fig. Se) exhibit a composition closer to the $\mathrm{PtTe}_{2}$ end-member, containing $5.87 \mathrm{wt} . \% \mathrm{Bi}, 2.28 \mathrm{wt}$ \% $\mathrm{Pd}$ and 0.52 wt. $\% \mathrm{Ni}$.

\section{Other PGM}

The Os-Ir-As-S phases (possibly osarsite) occur enclosed in chalcopyrite from the disseminated ore, forming small rounded grains, whereas the Ir-As-S (possibly irarsite) and the Ir-Pt-As phases, always occur in a chalcopyrite veinlet.

\section{Cobaltite-gersdorfitte, CoAsS-NiAsS}

Three grains of cobaltite-gersdorffite were found in disseminated ore. They occur as single subidiomorphic crystals hosted by pyrrhotite (Fig. 8f). Their Ni, Co and Fe contents vary from 11.5 to $16.6,13.4$ to 17.9 , and 3.6 to $8.3 \mathrm{wt} . \%$, respectively, and they contain traces of Pd (up to $\mathbf{0 . 6 4}$ wt.\%), Pt (up to $\mathbf{0 . 9 6}$ wt.\%), Ir (up to $1.8 \mathrm{wt} . \%$ ) and $\mathrm{Rh}$ (up to $1.7 \mathrm{wt. \%}$ ). On the other hand, several small eu- to subhedral grains of this solid solution series were identified in a restricted area of a chalcopyrite veinlet inside chalcopyrite and pentlandite. These grains contain 22.3 wt.\% Co, 8.4 wt.\% Ni and 6.36 wt.\% Fe, but no PGE.

\section{Trace element contents of the $\mathrm{Ni}-\mathrm{Cu}-\mathrm{Fe}$ sulphides}

Micro-PIXE analysis uniquely reveal measurable concentrations of Se (64$199 \mathrm{ppm}), \mathrm{Ni}(4397-48410 \mathrm{ppm})$ and $\mathrm{Cu}(95-14694 \mathrm{ppm})$ in the pyrrhotite, Se (31-201 ppm) and $\mathrm{Zn}(154$ and $450 \mathrm{ppm})$ in pentlandite, Se $(29-134 \mathrm{ppm}), \mathrm{Ni}$ (2383-4483ppm) and $\mathrm{Ag}(25-71 \mathrm{ppm})$ in chalcopyrite and $\mathrm{Ni}(142-20666 \mathrm{ppm})$, Se $(<187 \mathrm{ppm})$ and $\mathrm{As}(39-534 \mathrm{ppm})$ in pyrite. Pd, Ru and $\mathrm{Rh}$ concentrations (except in one analysis of pyrite with $22 \mathrm{ppm} \mathrm{Rh}$ ) are always below their detection limits in all the analysed grains.

\section{Discussion}

\section{Segregation and fractionation of the sulphide melt}

The mineralogical assemblage composed of pyrrhotite-pentlandite-chalcopyrite occurring interstitial to a primary silicate framework, the good positive correlations between Ni, PGE and S (Fig. 3a, d), and the systematic association of PGM with magmatic sulphides support previous interpretations, which consider the Aguablanca 
$\mathrm{Ni}-\mathrm{Cu}$ ores as the result of the accumulation and fractional crystallisation of a magmatic sulphide melt (Lunar et al., 1997; Tornos et al., 2001; Ortega et al., 2004; Piña et al., 2006). According to these authors, the sulphide melt segregated from a fractionating silicate melt in a deep seated magma chamber and concentrated, due to its high density, in the floor of the chamber. The silicate magma together with the sulphides were later injected in the shallow crust giving rise to the orebody (e.z., Voisey's Bay deposit, Li and Naldrett, 1999). Sulphur saturation in the silicate melt could be promoted by the assimilation of S-rich black slates of the Serie Negra Formation. This is supported by sulphur and lead isotopic signatures of the ores (Casquet et al., 1998; Tornos et al., 1998), as well as by the existence of partially-digested xenoliths of black slates in the host Aguablanca gabbroic intrusion. However, S/Se ratios of the ores (from 2613 to 4710 ) are typical of mantlederived sulphides (Naldrett, 1981) and do not support the addition of $\mathbf{S}$ from an external source. Nevertheless, the $\mathrm{S} / \mathrm{Se}$ ratios of the Serie Negra black slates (ranging from 184 to 3300) are significantly lower than those of the ores and unusually low for this type of sedimentary rocks. Such low values can be produced by devolatilisation reactions and sulphur loss (with the consequent decrease of the $\mathrm{S} / \mathrm{Se}$ ratio) associated to the transformation of pyrite to pyrrhotite in the slates (e.g., Theriault and Barnes, 1998). Thus, the mixing of these S-depleted slates with the silicate melt does not increase, but lower the $\mathrm{S} / \mathrm{Se}$ ratio of the contaminated melt and, consequently, the $\mathrm{S} / \mathrm{Se}$ ratio of the ores.

The different types of ores described would form by the combined effect of multiple melt injections and the fractionation of the sulphide melt. The concentric distribution of the semi-massive and the disseminated ores sugzest that the disseminated ores formed earlier by the injection of a silicate melt containing dispersed droplets of unfractionated, immiscible sulphide melt. Later, a new injection of melt (containing higher proportions of immiscible sulphide melt) and carrying maficultramafic fragments from the deep, partially consolidated in rusion, led to the formation of the semi-massive ores. This late injection crossed through the almost consolidated gabbronorite that hosts the disseminated ores producing the zoned structure of the Aguablanca orebody.

The semi-massive ores display mineralogical and geochemical features which suzgest that they formed by the crystallisation of a monosulphide solid solution (mss), with partial sezrezation of a Cu-rich sulphide liquid. Among other things, they show: 1) large proportions of pyrrhotite and high pentlandite/chalcopyrite ratios (commonly above 4) and 2) $\mathrm{Ni} / \mathrm{Cu}$ ratios significantly higher than 1 (Table 1 ). In con rast, the disseminated ores seem to be formed from a more fractionated sulphide melt since they show: 1) low pentlandite/chalcopyrite ratios (commonly between 0.06 and 0.31 ) and 2) $\mathrm{Ni} / \mathrm{Cu}$ ratios commonly below unity (Table 1). However, this hypothesis is unlikely because the liquidus temperature of the silicate magma is higher than that of a fractionated sulphide liquid and thus it would be difficult for a fractionated sulphide liquid to disperse to form disseminated ore in the partially solidified igneous rocks. Therefore, the most likely hypothesis is that the disseminated ores represent an original unfractionated sulphide liquid retained as droplets in the gabbronorite.

The crystallisation of $m s s$ from the sulphide melt in the semi-massive ores gave rise to the segregation of a $\mathrm{Cu}$-rich residual melt which mobilised away from the 
core of the orebody, filling late fractures that crossed-cut the semi-massive (including some mafic-ultramafic fragments) and, mainly, the disseminated ores. These veins constitute the chalcopyrite veined ores.

\section{Behaviour of $P G E$ and origin of the PGM}

The positive correlation between total PGE and $\mathrm{S}$ contents in most samples (Fig. 3d), and the close association of PGM with the base-metal sulphides are interpreted to indicate that PGE were collected by the sulphide liquid during its segrezation. Thus, PGE contents of the disseminated ores would correspond to those of the parental silicate + sulphide melt, whereas PGE abundances in the semi-massive and chalcopyrite-veined ores would be the consequence of the fractional crystallisation of the sulphide melt. This interpretation is in agreement with the chemistry of the ores, since semi-massive ores are relatively richer in $\mathrm{Os,} \mathrm{Ir,} \mathrm{Ru}$ and $\mathrm{Rh}$, and have lower mantle-normalised Pd/Ir ratios than the disseminated ores and the chalcopyrite-veined ores. During the crystallisation of the mss, this phase concentrated most Os, Ir, Ru and Rh because of their high partition coefficient between mss and the residual, Cu-rich sulphide melt (Fleet et al., 1993; Li et al., 1996). The remarkable correlation among these metals $(\boldsymbol{\rho}>\mathbf{0 . 9 7})$ is a common feature of magmatic sulphide deposits (e.g., Chai and Naldrett, 1992; Maier and Barnes, 2003; Barnes, 2004), and evidences their similar behaviour during fractional crystallisation and their strong resistance to alteration, as it is further indicated by their mostly parallel mantle-normalised patterns (Fig. 4). Although the scarcity of Os, Ir, Ru and Rh minerals sugzest that most of them should be in solid solution in pyrrhotite and pentlandite, as occurs in the Noril'sk (Czamanske et al., 1992; Distler and Kunilov, 1994) and Jinchuan (Chai et al., 1993) deposits, the obtained micro-PIXE data on $\mathrm{Ru}$ and $\mathrm{Rh}$ evidence that their concentration is always below the detection limit of the technique (4-11 ppm Ru and 6-13 ppm Rh).

During fractional crystallisation of a sulphide melt, Pt and Pd partitioned to the residual Cu-rich sulphide melt (Fleet et al., 1993; $L i$ et al., 1996), leaving the mss relatively impoverished in these noble metals. Consequently, Pt and Pd should tend to concentrate in the chalcopyrite veinlets. In fact, Pd bismuthotellurides are specially abundant in these veins. However, the degree of depletion of Pt and Pd in the semi-massive ores (representing the mss) compared with the disseminated ores (representing the unfractionated sulphide melt) is very small (Fig. 4). This could be related with the mechanism of emplacement of the sulphide melts in shallow crustal levels. Just after each injection, thermal diffusion towards the cooler host should promote rapid cooling of the melt. This allowed to preserve the original composition of the sulphide droplets in the disseminated ores and prevented extensive fractionation of the sulphide melt in the semi-massive ores. Thus, only small amounts of $\mathrm{Cu}$-rich, residual sulphide melt generated, forming some few chalcopyrite veinlets (they represent $<1$ vol.\% of the $\mathrm{Ni}-\mathrm{Cu}$ ores). In this scenario, most $\mathrm{Pt}$ and $\mathrm{Pd}$, as well as Te, Bi and As, remained in the mss during the early stages of cooling and, later, exsolved giving rise to the described PGM assemblage in the semi-massive and in the disseminated ores.

Experimental results by Hoffmann and MacLean (1976) show that the Bi content of merenskyite lowers its thermal stability and that its coexistence with 


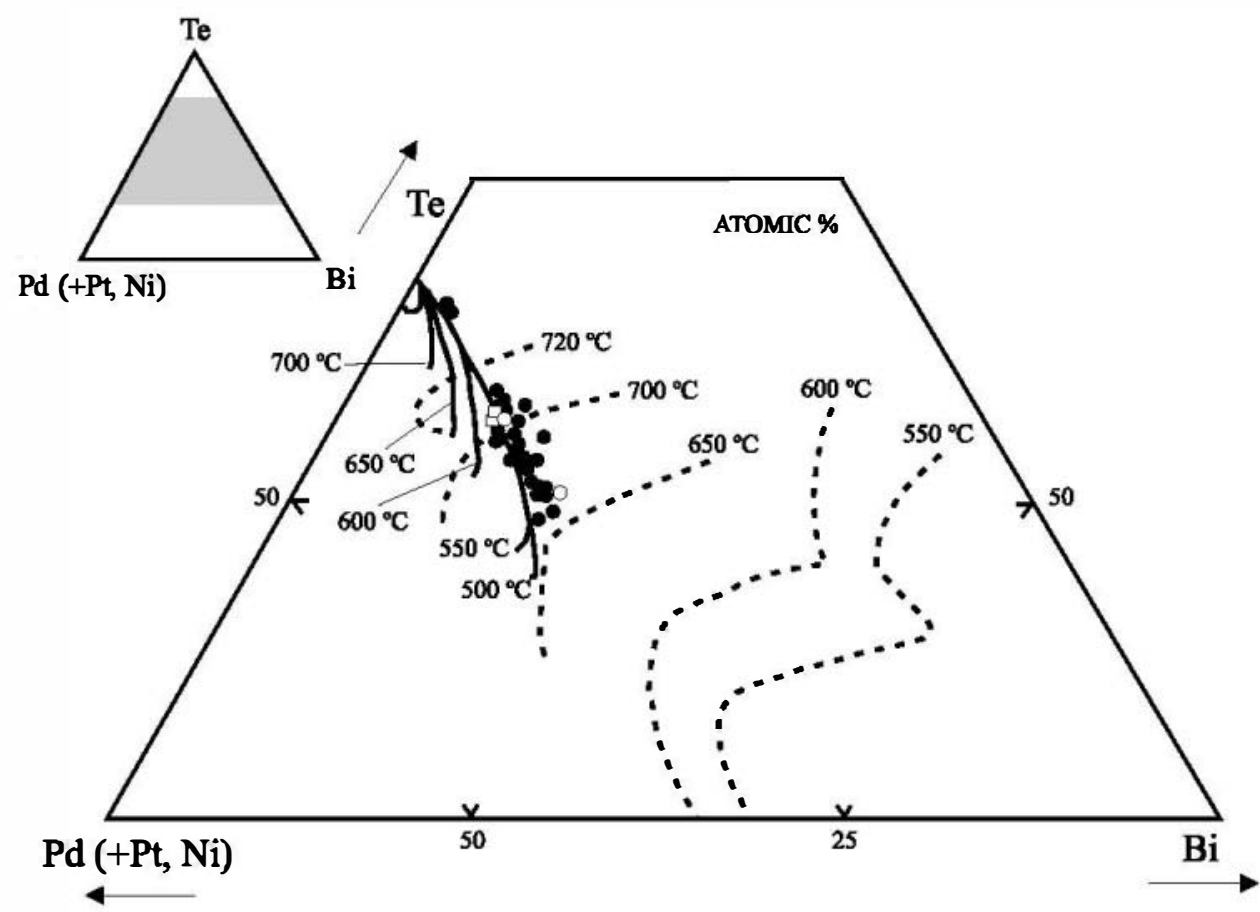

Fig. 9. Plot of merenskyites at Aguablanca in the system Pd (+Pt, Ni)-Te-Bi. Solid lines correspond to the compositions of merenskyite at different temperatures, whereas the dashed lines represent compositions of the coexisting liquid. After H•ffman and MacLean (1976). Symbols as for Figs. 3-5 and 8

michenerite limits the stability of the assemblaze to temperatures below $500^{\circ} \mathrm{C}$. The merenskyite compositions at Aguablanca reveals crystallisation temperatures below $500^{\circ} \mathrm{C}$ (Fig. 9). Nevertheless, more recent experiments by Helmy et al. (2005) (and Helmy, written communication) have checked the solubility of Pt, Pd and $\mathrm{Te}$ in a $(\mathrm{Fe}, \mathrm{Cu}, \mathrm{Ni})_{1-\mathrm{x}} \mathrm{S}$ melt from 1015 to $370^{\circ} \mathrm{C}$. Their results show that $\mathrm{Pt}-\mathrm{Pd}-\mathrm{Ni}$ tellurides cannot be formed at temperatures above $370^{\circ} \mathrm{C}$ due to the low concentration of these elements in the original melt and their high solubility in the mss, which depend on the bulk Te content and the $\mathrm{Te} /(\mathrm{Pt}+\mathrm{Pd})$ ratio of the sulphide melt. Furthermore, they show that the assemblage merenskyite-moncheitepalladian melonite can be formed only from melts with $\mathrm{Te} /(\mathrm{Pt}+\mathrm{Pd})>2$. As is shown in Table 2, all but one [with $\mathrm{Te} /(\mathrm{Pt}+\mathrm{Pd})=1.85$ ] of the analysed samples from disseminated ores (representing the original, unfractionated melt) exhibit $\mathrm{Te} /(\mathrm{Pt}+\mathrm{Pd})$ ratios above 2 , in agreement with the described Pd-Pt-Ni bismuthotelluride assemblaze. Consequently, the PGMs of the Azuablanca Ni-Cu deposit formed at very low temperature by exsolution from $m s s$ and chalcopyrite on cooling. Nevertheless, as it will be discussed below, such assemblages and the bulk distribution of some elements were partially modified by late hydrothermal fluids.

\section{Role of hydrothermal fluids}

It is well documented that $\mathrm{Cu}$ behaves compatibly during the segregation of a sulphide liquid from the silicate melt (Rajamani and Naldrett, 1978) and consequently 
a good correlation between $\mathrm{Cu}$ and $\mathrm{S}$ would be expected. However, the lack of correlation between these elements in the Aguablanca ores suggests a redistribution of copper by secondary processes such as hydrothermal alteration (e.z., Jinchuan deposit; Chai and Naldrett, 1992).

The extensive circulation of hydrothermal fluids in Azuablanca is evidenced by the retrograde alteration of the host rocks and the replacement of pyrrhotite by pyrite in three successive episodes under progressively decreasing temperature. The precipitation of pyrite started early in the postmagmatic history of the deposit $\left(\sim 500^{\circ} \mathrm{C}, \mathrm{Py}_{1}\right)$ and took place along a broad period coeval with the subsolidus recrystallisation of the magmatic ores and the overall cooling of the deposit (Ortega et al., 2004). The hydrothermal fluids always had higher $f \mathrm{O}_{2}$ and $f \mathrm{~S}_{2}$ than the sulphide assemblage as is indicated by the transformation of pyrrhotite into pyrite along the three recognised hydrothermal stages. However, effective copper remobilisation only took place during the second stage as shown by the occurrence of fluid-precipitated chalcopyrite along cleavage planes of secondary actinolite and chlorite, and surrounding the $\mathrm{Py}_{2}$ crystals. The actinolite \pm chlorite \pm epidote \pm calcite alteration assemblage indicates fluids with neutral to mild alkaline $\mathrm{pH}$ and circulation temperature of around $350^{\circ} \mathrm{C}$.

The high correlation between $\mathrm{Au}$ and $\mathrm{Cu}$ (Fig. 3a) indicates that gold was also mobilised by these fluids. This is further supported by its highly scattered distribution in the ores and the pronounced negative anomalies in the mantle-normalised patterns (Fig. 4).

Pt also shows nezative anomalies in the different ore types (Fig. 4). Negative Pt anomalies are characteristic of sulphides representing crystallisation of mss (Barnes et al., 1997), indicating its low partition coefficient for this phase, being concentrated, like $\mathrm{Pd}, \mathrm{Cu}$ and $\mathrm{Au}$ in the $\mathrm{Cu}$-rich, residual sulphide liquid. However, in Aguablanca the occurrence of these anomalies not only in the semi-massive ore (mss), but also in the disseminated ores (the unfractionated original melt) and in the chalcopyrite veins ( $\mathrm{Cu}$-rich residual liquid) (Fig. 4) suggests that Pt also underwent hydrothermal remobilisation. Mineralogical evidence include inclusions of moncheite found in secondary actinolite (Fig. Be) and irregular edges of sperrylite at the contact with secondary chlorite (Fig. 8c), suggesting partial dissolution of Pt-bearing phases by hydrothermal solutions.

Theoretical and experimental data (Gammons et al., 1992; Wood, 2002) show that Pd and Pt are mobile elements which can be transported in hydrothermal fluids under certain conditions. Especially, $\mathrm{Pt}$ is highly soluble in $\mathrm{Cl}$-rich aqueous fluids at temperatures between 25 and $300^{\circ} \mathrm{C}$ (Gammons et al., 1992). Nevertheless, if these fluids were involved in the mobilisation of $\mathrm{Pt}$, as seems to be the case, negative anomalies should be observed also for Pd and this does not occur. The preferential remobilisation of Pt over Pd by postmazmatic hydrothermal fluids can be tentatively explained in terms of the factors affecting the solubility of these metals in the aqueous fluid.

In magmatic-hydrothermal environments, between 500 and $300^{\circ} \mathrm{C}$, copper is preferentially dissolved in hypersaline, neutral-weak acidic, and intermediatereduced solutions and mainly transported as $\mathrm{CuCl}_{2}^{-}$( Liu and McPhail, 2005 and references therein). Major factors controlling chalcopyrite deposition are decrease of temperature, and salinity (i.e., $\mathrm{Cl}$ availability), and to a lesser extend, decrease of 
$f \mathrm{O}_{2}$ and increase of $\mathrm{pH}$ and $f \mathbf{S}_{2}$. At Aguablanca, where geochemical and mineralogical evidences indicate that chalcopyrite was remobilised by hydrothermal fluids and precipitated azain at around $350^{\circ} \mathrm{C}$, these factors would have competed among them in the solubility reactions of copper and therefore, dissolution of chalcopyrite was limited. As the fluids circulated and the deposit cooled down, the fluid became saturated in chalcopyrite around $350^{\circ} \mathrm{C}$ and the decrease of temperature probably played a major role.

Gold can be transported either as $\mathrm{Au}(\mathrm{HS})_{2}{ }^{-}$or as $\mathrm{AuCl}_{2}{ }^{-}$, the latter being the dominant complex above $300^{\circ} \mathrm{C}$ (Romberger, 1991). The stability of the $\mathrm{AuCl}_{2}{ }^{-}$ strongly decreases with decreasing temperature and salinity. This is, therefore in agreement with the mobilisation, transport, and precipitation of copper indicated above.

$\mathrm{Pt}$ and Pd can also be transported as chloride complexes at temperatures above $300{ }^{\circ} \mathrm{C}, \mathrm{PtCl}_{3}{ }^{-}$and $\mathrm{PdCl}_{4}{ }^{2-}$, respectively, being the dominant species (Wood, 2002). At given $\mathrm{pH}, \mathrm{a}\left[\mathrm{Cl}^{-}\right]$, and $f \mathrm{O}_{2}$ conditions, these metals exhibit retrograde solubility, i.e., their solubility decrease as temperature increases. However, if the $f \mathrm{O}_{2}$ is buffered by a mineralogical assemblaze, as it is in Azuablanca by the transformation pyrrhotite $\rightarrow$ pyrite in the postmagmatic stages, the solubility decreases with decreasing temperature. In addition, as any chloride complex, the $\mathrm{Pd}$ and Pt-complexes stabilities are strongly dependent of the salinity (i.e., a $\left[\mathrm{Cl}^{-}\right]$). This is a key point in understanding the different behaviour of $\mathrm{Pt}$ against $\mathrm{Pd}$ during the hydrothermal remobilisation of metals. At temperatures above $300^{\circ} \mathrm{C}, \mathrm{Cu}, \mathrm{Au}$, $\mathrm{Pt}$ and $\mathrm{Pd}$ will be transported in solution as $\mathrm{CuCl}_{2}{ }^{-}, \mathrm{AuCl}_{2}{ }^{-}, \mathrm{PtCl}_{3}{ }^{-}$and $\mathrm{PdCl}_{4}{ }^{2-}$, respectively. Thus, in a fluid with a given concentration of chlorine, the facility of forming chloride complexes increases following the order $\mathrm{Pd} \rightarrow \mathrm{Pt} \rightarrow \mathrm{Cu}$, Au. Therefore, the avidity of copper for chlorine, together with the much higher abundance of copper than Pt and Pd in the deposit, will result in a preferential dissolution of copper, and subsequently of gold, over Pt and Pd. This could drastically reduce the availability of chlorine to form $\mathrm{Pt}$ and Pd complexes, thus resulting in a very limited remobilisation of $\mathrm{Pt}$ (most of the Pt minerals remain in the sulphide ore) and a negligible dissolution of $\mathrm{Pd}$, more sensitive to the $\mathrm{a}\left[\mathrm{Cl}^{-}\right]$) of the fluid than Pt. The metal remobilisation, developed at $\mathrm{T}>350^{\circ} \mathrm{C}$ probably was partially coeval with the exsolution of Pd and Pt from the mss below $370^{\circ} \mathrm{C}$, and this could aid to the observed Pt remobilisation.

\section{Acknowledgements}

The authors are very grateful to Río Narcea Recursos S. A. (owner of the deposit) and especially to Mr. C. Maldonado and C. Martínez for the facilities given for carrying on of this research. We greatly acknowledge Prof. H. Helmy for his help in the discussion of the genesis of Pt-Pd-Ni bismuthotellurides, allowing us to use his partly unpublished experimental data. Our work has greatly benefited from the discussions with Prof. S. Wood at the 10 th Platinum Symposium at Oulu. Professor J. González de Tánago and Mr. A. Larios kindly assisted in the electron-probe micro-analyses. We thank Prof. J. L. Campbell of the Guelph University for his assistance during the PLXE analyses. We thank two reviewers, Prof. S. J. Barnes and C. Ferreira, for their constructive reviews and Tuomo Alapieti for his editorial input which have helped to improve the manuscript. This research was supported by the Spanish Ministry of Education and Science, Project BTE2003-03599. 


\section{References}

Barnes SJ (2004) Komatiites and nickel sulphides ores of the Black Swan area, Yilgarn Craton, Western Australia. 4. Platinum group element distribution in the ores, and genetic implications. Mineral Deposita 39: 752-765

Barnes SJ, Lightfot PC (2005) Formation of magmatic nickel-sulfide ore deposits and processes affecting their copper and platinum-group elements contents. In: Hedenquist $J W$, Thompson JFH, Goldfarb RJ, Richards JP (eds) Economic Geology One Hundreth Anniversary Volume, pp 179-213

Barnes SJ, Makovicky E, Makovicky M, Rose-Hansen J, Karup-Møller S (1997) Partition coefficients for $\mathrm{Ni}, \mathrm{Cu}, \mathrm{Pd}, \mathrm{Pt}, \mathrm{Rh}$ and Ir between monosulphide solid solution and sulfide liquid and the formation of compositionally zoned $\mathrm{Ni}-\mathrm{Cu}$ sulfide bodies by fractional crystallization of sulfide liquid. Can J Earth Sci 34: 366-374

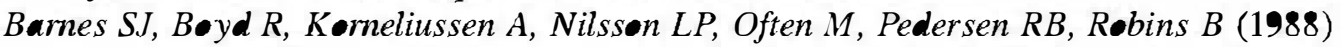
The use of mantle normalization and metal ratios in discriminating between the effects of partial melting, crystal fractionation and sulphide segregation on platinum-group elements, gold, nickel and copper: examples from Norway: In: Prichard HM, Potts PJ, B॰wles JFW, Cribb SJ (eds) Geo-platinum 87. Elsevier, London, pp 113-143

Cabri LJ (2002) The platinum-group minerals: In: Cabri LJ (ed) The geology, mineralogy and mineral beneficiation of platinum-group elements. Canadian Institute of Mining and Metallurgy, Spec Vol. 54, pp 13-129

Casquet $C$, Eguiluz L, Galinde C, Tornes F, Velasce F (1998) The Aguablanca Cu-Ni-(PGE) intraplutonic ore deposit (Extremadura, Spain). Isotope ( $\mathrm{Sr}, \mathrm{Nd}, \mathrm{S}$ ) constraints on the source and evolution of magmas and sulphides. Geogaceta 24: 71-72

Casquet C, Galinde C, Tornes F, Velasce F, Canales A (2001) The Aguablanca Ni-Cu-(PGE) intraplutonic ore deposit (Extremadura, Spain), a case of synorogenic orthomagmatic mineralization: age and isotope composition of magmas ( $\mathrm{Sr}, \mathrm{Nd}$ ) and (S). Ore Geol Rev 18: $237-250$

Chai G, Naldrett AJ (1992) PGE mineralization of the Jinchuan Ni-Cu sulfide deposit, NW China. Econ Geol 87: 1475-1495

Chai G, Naldrett AJ, Rucklidge JC, Kilius LR(1993) In situ quantitative analyses of PGE and $\mathrm{Au}$ in sulfide minerals of the Jinchuan $\mathrm{Ni}-\mathrm{Cu}$ deposit by accelerator mass spectrometry. Can Mineral 31: 19-30

Czamanske GK, Kunilov VR, Zientek ML, Cabri LJ, Likhachev AP, Calk LC, Oscarson RL (1992) A proton-microprobe study of magmatic sulfide ores from the Noril'sk-Talnakh district, Siberia. Can Mineral 30: 249-287

Daltry VV, Wilson VE (1997) Review of platinum-group mineralogy: compositions and elemental associations of the PG-minerals and unidentified PGE-phases. Mineral Petrol 60: $185-229$

Distler VV, Kunilov VE (1994) Geology and ore deposit of the Noril'sk region. Guidebook, VII International Platinum Symposium. The International Association on the genesis of ore deposits. Russian academy of science, Moscow, 67 pp

Eguiluz L, Gil Ibarguchi JI, Abalos B, Apraiz A (2000) Superposed Variscan and Cadomian orogenic cycles in the Ossa-Morena zone and related areas of the Iberian Massif. Geol Soc Am Bull 112: 1398-1413

Evans-Lamswood DM, Butt DP, Jackson RS, Lee DV, Muggridge MG, Wheeler RI, Wilton DHC (2000) Physical controls associated with the distribution of sulfides in the Voisey's Bay Ni-Cu-Co deposit, Labrador. Econ Geol 95: 749-769

Fleet ME, Chryssoulis SL, Stone WE, Weisener CG (1993) Partitioning of platinum-group elements and $\mathrm{Au}$ in the $\mathrm{Fe}-\mathrm{Ni}-\mathrm{Cu}-\mathrm{S}$ system: experiments on the fractional crystallization of sulphide melt. Contrib Mineral Petrol 115: 36-44 
Gammons $\mathrm{CH}$, Bloom MS, Yu Y (1992) Experimental investigations of the hydrothermal geochemistry of platinum and palladium. I. Solubility of platinum and palladium sulphide minerals in $\mathrm{NaCl} / \mathrm{H}_{2} \mathrm{SO}_{4}$ solutions at $300^{\circ} \mathrm{C}$. Geochim Cosmochim Acta 56: $3881-3894$

Gervilla $F$, Kojonen $K$ (2002) The platinum-group minerals in the upper section of the Keivitsansarvi Ni-Cu-PGE deposit, northern Finland. Can Mineral 40: 377-394

Harney DMW, Merkle RKW (1990) Pt-Pd minerals from the upper zone of the Bushveld Complex, South Africa. Can Mineral 28: 619-628

Helmy HM, Ballhaus C, Berndt-Gerdes J (2005) The formation of Pt, Pd and Ni tellurides during cooling of $\mathrm{Fe}-\mathrm{Ni}-\mathrm{Cu}$ sulphide: results of experiments and implications for natural systems. Geochem Miner Petrol 43: 87-92

Hoffman E, MacLean WH (1976) Phase relations of michenerite and merenskyite in the Pd-Bi-Te system. Econ Geol 71: 1461-1468

Li C, Naldrett AJ (1999) Geology and petrology of the Voisey's Bay intrusion: reaction of olivine with sulfide and silicate liquids. Lithos 47: 1-31

Li C, Barnes SJ, Makovicky E, Rose-Hansen J, Makovicky M (1996) Partitioning of Ni, Cu, Ir, Rh, Pt and Pd between monosulphide solid solution and sulphide liquid: effects of composition and temperature. Geochim Cosmochim Acta 60: 1231-1238

Liu W, McPhail DC (2005) Thermodynamic properties of copper chloride complexes and copper transport in magmatic-hydrothermal solutions. Chem Geol 221: 21-39

Lunar R, Garcia-Palomere F, Ortega L, Sierra J, Moren॰ T, Prichard $H$ (1997) $\mathrm{Ni}-\mathrm{Cu}-(\mathrm{PGM})$ mineralization associated with mafic and ultramafic rocks: the recently discovered Aguablanca ore deposit, SW Spain. In: Papunen $H$ (ed) Mineral deposits: research and exploration. Where do they meet? Balkema, Rótterdam, pp 463-466

Maier WD, Barnes SJ (2003) Platinum group elements in the Boulder Belt, western Bushveld complex, South Africa. Mineral Deposita 38: 370-380

Maxwell JA, Campbell JL, Teesdale WJ (1989) The Guelph PIXE software package. Nucl Instr Methods Phys Res 43: 218-230

McDonough WF, Sun SS (1995) The composition of the Earth. Chem Geol 120: 223-253

Naldrett $A J$ (1981) Nickel sulfide deposits: classification, composition and genesis. Econ Geol 75: 628-685

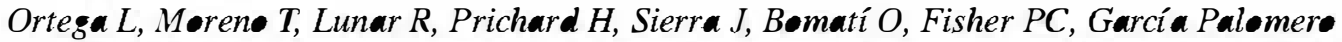
$F$ (1999) Minerales del grupo del platino y fases asociadas en el depósito de Ni-Cu-EGP de Aguablanca, SW España. Geogaceta 25: 155-158

Ortega L, Prichard H, Lunar R, Garcia Palomere F, Moren॰ T, Fisher PC (2000) The Aguablanca discovery. Mineral Mag 2: 78-80

Ortega L, Lunar R, Garcia Palomere F, Moren॰ T, Prichard H (2001) Remobilización de minerales del grupo del platino en el yacimiento de Ni-Cu-EGP de Aguablanca (Badajoz). Boletín de la Sociedad Española de Mineralogía 24: 175-176

Ortega L, Lunar R, García Palomer F, Møren॰ T, Martín Estévez JR, Prichard HM, Fisher PC (2004) The Aguablanca Ni-Cu-PGE deposit, southwestern Iberia: magmatic oreforming processes and retrograde evolution. Can Mineral 42: 325-350

Piña R, Lunar L, Ortega L, Gervilla F, Alapieti T, Martínez $C$ (2004) Origen de los fragmentos máficos-ultramáficos de la brecha mineralizada del yacimiento de Ni-Cu-EGP de Aguablanca (Badajoz). Revista de la Sociedad Española de Mineralogía 2: $19-20$

Piña R, Gervilla F, Ortega L, Lunar $R$ (2005) Geochemistry and mineralogy of platinumgroup elements in the Aguablanca Ni-Cu deposit (SW Spain). In: Törmänen TO, Alapieti TT (eds) Platinum-group elements - from genesis to beneficiation and environmental impact, 10th Int. Platinum Symposium, Extended Abstracts, Oulu, pp 215-218 
Piña R, Lunar L, Ortega L, Gervilla F, Alapieti T, Martínez C (2006) Crystal fractionation and sulfide segregation processes in the source chamber of the Aguablanca Ni-Cu-PGE deposit (SW Spain). Econ Geol (in press)

Quesada $C$ (1991) Geological constraints on the Paleozoic tectonic evolution of the tectonostratigraphic terranes in the Iberian Massif. Tectonophysics 185: 225-245

Quesada C, Munha $J$ (1990) Metamorphism. In: Dallmeyer RD, Martínez García E (eds) Premesozoic Geology of Iberia. Springer Verlag. Heidelberg, pp 314-320

Quesada C, Fonseca PE, Munhá PE, Oliveira JM, Ribeire A (1994) The Beja-Acebuches Ophiolite (Southern Iberia Variscan foldbelt): geological characterization and geodynamic significance. Boletín Geológico y Minero 105: 3-49

Rajamani V, Naldrett AJ (1978) Partitioning of $\mathrm{Fe}, \mathrm{Co}, \mathrm{Ni}$ and $\mathrm{Cu}$ between sulphide liquid and basaltic melt and the composition of Ni-Cu sulfide deposits. Econ Geol 73: 82-93

Riveire A, Quesada C, Dallmeyer RD (1990) Geodynamic evolution of the Iberian Massif. In: Dallmeyer RD, Martinez Garci $E$ (eds) Premesozoic geology of Iberia. Springer Verlag, Heidelberg, pp 399-409

Remberger $S B$ (1991) Transport and deposition of precious metals in epithermal deposits. In: Raines GL, Lisle RE, Richard E, Schafer RW, Wilkinson WH (eds) Geology and ore deposits of the Great Basin. Symposium Proc. Geol Soc Nevada, Reno, Nevada, pp 219-232

Rome• I, Lunar R, Capote R, Quesada C, Dunning GR, Piña R, Ortega L (2004) Edades de cristalización U-Pb en circones del complejo ígneo de Santa Olalla de Cala: implicaciones en la edad del yacimiento de Ni-Cu-EGP de Aguablanca (Badajoz). Revista de la Sociedad Española de Mineralogía 2: 29-30

Sánchez Carreter $R$, Eguiluz L, Pascual E, Carracede $M$ (1990) Igneous rocks of the Ossa-Morena Zone. In: Dallmeyer RD, Martínez García $E$ (eds) Premesozoic geology of Iberia. Springer Verlag, Heidelberg, pp 292-313

Theriault RD, Barnes SJ (1998) Compositional variations in Cu-Ni-PGE sulphides of the Dunka road deposit, Duluth complex, Minnesota: the importance of combined assimilation and magmatic processes. Can Mineral 36: 869-886

Tornos F, Chiaradia M, Fontboté L (1998) La geoquímica isotópica del plomo en las mineralizaciones de la Zona de Ossa Morena (ZOM): implicaciones metalogenéticas y geotectónicas. Boletín de la Sociedad Española de Mineralogía 21: 206-207

Tornes F, Casquet C, Galinde C, Velasce F, Canales $A$ (2001) A new style of $\mathrm{Ni}-\mathrm{Cu}$ mineralization related to magmatic breccia pipes in a transpressional magmatic arc, Aguablanca, Spain. Mineral Deposita 36: 700-706

Tornos F, Irionde C, Casquet C, Galinde C (2004) Geocronología Ar-Ar de flogopitas del stock de Aguablanca (Badajoz). Implicaciones sobre la edad del plutón y de la mineralización de $\mathrm{Ni}-(\mathrm{Cu})$ asociada. Geotemas 6: 189-192

Wood $S A$ (2002) The aqueous geochemistry of the platinum-group elements with applications to ore deposits. In: Cabri LJ (ed) The geology, mineralogy and mineral beneficiation of platinum-group elements. Canadian Institute of Mining and Metallurgy, Spec Vol. 54, pp 211-249

Authors' addresses: R. Piña (corresponding author; e-mail: rpinagar@geo.ucm.es),L.Ortega (e-mail: lortega@geo.ucm.es),R. Lunar (e-mail: lunar@geo.ucm.es), Departamento de Cristalografia y Mineralogía, Facultad de Geología, Universidad Complutense de Madrid, ES-28040 Madrid, Spain; F. Gervilla (e-mail: gervilla@ugr.es), Facultad de Ciencias, Instituto Andaluz de Ciencias de la Tierra, Universidad de Granada-CSIC, Avda. Fuentenueva, s/n, ES-18002 Granada, Spain 